śrīganeśāāya namaḥ ||

gaṇādhipạ̣ rāmaguroḥ padābjaṃ dāmodarākhyam pitaraṃ ca natvā | prācīnapadyair balabhadranāmā karoti saddhāyanaratnasaṃjñam || bhāgīrathītīravirājamāne śrīkānyakubje nagare 'tiramye | abhūd bharadvājamaharṣivaṃśe śrīlālanāmā gaṇakoṣṇadhāmā || tasyātmajāḥ pañca babhūvur eșāṃ śrīdevidāsaḥ prathamaṃ babhūva | vyakte ca yah śrīpatipaddhatau ca țīkāṃ vyadhāc chiṣyagaṇasya tuștyai || tasmāl laghuḥ khețavicāradakșaḥ prakhyātakīrtir vijitāripakșaḥ | śrīkṣemakarṇo 'tha tataḥ kanișṭho nārāyaṇo vyākaraṇe pațișṭhạ || nyāye yaḥ surarājapūjitanibho vedāntinām agraṇīr mīmāṃsādisamastaśāstrakamalaprodbodhane bhāskaraḥ| śrīmadbhūpativṛndapūjitapado bhūdevamūrdhāmaṇiḥ śrīmanmiśracaturbhujạ̣ samabhavat tasmāl laghur dharmavit || tasmāl laghuh sakalaśāstrakalāpațiștho dāmodarah samabhavat kṛtināṃ varișțhạ | yo bhāskaroditapitāmahakarmatulyavṛttiṃ vyadhān nirupamāṃ kṛtināṃ hitāya || dāmodarasya tanayau jātau balabhadraharirāmau | balabhadreṇa ca kiṃcit prakāśyate tājikaṃ guroḥ kṛpayā ||

1 namaḥ] śrīgurubhyo namah || śrīsarasvatyai namaḥ add. G; śrīgurucaraṇakamalebhyo namah \| oṃ add. K T M 5 gaṇakoṣnadhāmā] gaṇakopanāmā M $\quad 7$ vyakte] vyaktạ̣ M 16 -odita] -otita B 18 harirāmau] balirāmau K T M 


\section{Fundamentals of Astrology and the Annual Revolution}

\subsection{The Author's Family Lineage}

\section{Homage to Śrī Gaṇeśa!}

Saluting Ganeśa, the lotus feet of his teacher Rāma, and his father Dāmodara, [the author] named Balabhadra composes the true [work] called Hāyanaratna with verses of old.

In the most beautiful town of Kānyakubja, shining on the bank of the Ganges, a sun among mathematicians named Śrī Lāla was born in the lineage of the great sage Bharadvāja. He had five sons: among them, the first-born was Śrī Devidāsa, who composed a gloss on the Vyakta and the Śripatipaddhati to please his assembly of students. ${ }^{1}$ His junior was Śrī Kṣemakarṇa, skilled in the judgement of the planets, of wide renown, vanquisher of his opponents. Younger than he was Nārāyaṇa, most skilled in grammar. Śrī Miśra Caturbhuja was born as his junior, a knower of law who in logic resembled [Brhaspati, the preceptor] worshipped by the king of gods; who was foremost among knowers of Vedānta, a sun causing the lotus of all sciences, beginning with Mīmāṃsā, to blossom; whose feet were worshipped by multitudes of illustrious kings; and who was the crown jewel of the Brahmans. As his junior Dāmodara was born, most skilled in all sciences and arts, the greatest of the learned, who for the benefit of the learned composed an incomparable commentary on the Pitāmahakarmatulya authored by Bhāskara. ${ }^{2}$ To Dāmodara were born the sons Balabhadra and Harirāma; and Balabhadra [now] reveals something of Tājika by the grace of his teacher.

1 Vyakta appears to be the name, or perhaps popular designation, of an unidentified work.

2 Pitāmahakarmatulya is presumably an alternative title for Bhāskara's Brahmatulya (also known as Karanakutūhala), pitāmaha 'grandfather' being a common epithet of the creator deity Brahmā. 
nibandhā racitāḥ pūrvaiḥ saṃhitājātakādișu | na hāyanaphale tasmān nibandhaṃ kartum udyatạ̣ \| hillājakhattakhuttāryakhindhiromakasammatam | sāraṃ samarasiṃhasya kriyate vārṣikaṃ phalam ||

nanu kimabhidheyakam idaṃ śāstraṃ prayojanaṃ ca kim | uktaṃ ca |

jñātārthaṃ jñātasambandham śrotuṃ śrotā pravartate | granthädau tena vaktavyaḥ sambandhah saprayojanah || iti |

anyac ca $\mid$

sarvasyaiva hi śāstrasya karmaṇo vāpi kasyacit |

yāvat prayojanam noktam tāvat tat kena grhyate || iti |

ucyate | yavanācāryeṇa pārasyā bhāṣayā pranītaṃ jyotiḥsāāstraikadeśarūpaṃ vārṣikādinānāvidhaphalādeśaphalakaṃ śāstram tājikaśabdavācyam | tadanantarasambhūtaih samarasiṃhādibhir adhītavyākaranair brāhmaṇais tad eva śāstram saṃskṛtaśabdopanibaddhạ̣ tad api tājikaśabdavācyam eva | ata evaitais tā eva ikkavālādayo yāvantyah saṃjñā upanibaddhāḥ | atra graharāśisvarūpașoḍaśayogasahamasāngavarșaphalabhāvavicāradaśāvibhāgagamanāgamanādyanekapraśnarūpās tājikapadārthāḥ pratipādyatvena viṣayabhūtāḥ | eșām padārthānāṃ tājikagranthasya ca pratipādyapratipādakabhāvaḥ sambandhah | prayojanaṃ tu bhūtabhaviṣadvartamānaśubhāśubhaphalakathanam | uktaṃ ca nāradena |

1 saṃhitā] saṃhitās M || jātakādiṣu] tājikādiṣu K T M 16 sahamasānga] sahamāsānga M 17-18 pratipādyatvena] pratipādya tena KT; pratipādyaṃte na M 19 tu] caKTM || bhūta] om. N

6-7 jñātārtham ... saprayojanaḥ] ŚV 1.17 9-10 sarvasyaiva ... gṛhyate] ŚV 1.12

1 jātakādișu] The tājaka (tājika)/ jātaka metathesis is not uncommon in Mss and editions of Tājika works. 
Earlier authors have composed digests on natural astrology, genethlialogy and so forth, [but] not on the results [of the revolutions] of the years; therefore, $[\mathrm{I} \mathrm{am}]$ undertaking to produce such a digest. [Here] the results pertaining to the year are set forth: the essence of [the work of] Samarasimha, approved by Hillāja, the noble Khattakhutta, Khindhi and Romaka. ${ }^{3}$

Objection: what is the subject matter of this science, and what is its purpose? ${ }^{4}$ For it is said [in Ślokavārttika 1.17]:

The listener proceeds to listen to that [topic] the purpose and relation of which are known; therefore the relation should be stated at the beginning of a book, along with the purpose.

And also [in Ślokavārttika 1.12]:

Until the purpose of any science or undertaking whatever is stated, how can it be grasped?

[In reply] it is said: the word Tajika denotes the treatise composed by Yavanācārya in the Persian language, comprising one area of astrology and having for its outcome the prediction of the various kinds of results of annual [horoscopy] and so on. That same treatise was rendered into the Sanskrit language by those born after him, Samarasimha and other Brahmans versed in grammar, and that [work], too, is denoted by the word Täjika. Therefore they too use the same terms, such as ikkavāla and so on. And by being set forth here, the Tajika concepts in the form of the natures of the planets and signs, the sixteen configurations, the sahamas, the results of the years with their parts, the judgement of houses, the division of periods, numerous questions on coming and going and so on, comprise its subject matter. And the condition of being set forth and setting forth, pertaining to these concepts and to the Tajjika book, [respectively], is the relation. And the purpose is describing the good and evil results of the past, present and future. For Nārada says [in Nāradasaṃhitā 1.5]:

3 For the identities of the authorities cited here, see the Introduction.

4 This question introduces the anubandha-catuștaya or four constituents of any śāstra: abhidheya 'subject matter', prayojana 'purpose', sambandha 'relation' and adhikāra 'qualification'. The latter two are discussed shortly below. 
prayojanam tu jagatah śubhāśubhanirūpaṇam | iti |

atra śāstre varṣaphalapraśnādijijñāsur adhikārī| sa ca brāhmaṇa eva | uktaṃ ca vasișțhena |

adhyetavyaṃ brāhmanair eva tasmāj

jyotihśāastram punyam etad rahasyam |

etad buddhvā samyag āpnoti yasmād

arthaṃ dharmaṃ mokșam agryaṃ yaśaś ca || iti |

nanu yavanācāryapraniitekkavālādipārasisśabdātmakasya tājikaśāstrasyādhyayanam eva tāvad anabhihitam adhyāpanaṃ tu dūrād apāstam eva | uktam ca smṛtau |

na vaded yāvanīm bhāṣāṃ prāṇaiḥ kaṇṭhagatair api | iti |

tanmūlabhūtatvāt samarasiṃhādiśāstrasyāpy adhyayanam anucitaṃ mūlāśuddhyā sarvam aśuddham iti nyāyāt ||

atrocyate | yavanācāryasyāṣțādaśasaṃhitākartṛṣu pariganitatvāt tadvacah pramāṇam eva | uktaṃ ca kaśyapena |

sūryaḥ pitāmaho vyāso vasiștho 'trị parāśaraḥ|

kaśyapo nārado gargo marīcir manur añgirāḥ $\|$

lomaśa h pauliśaś caiva cyavano yavano bhrguḥ|

śaunako 'ștādaśāś caite jyotiḩśāstrapravartakāḥ || iti |

2 śāstre] tu add. K T M 5 rahasyam] grahasyam B N G a.c. $\quad 8-9$-ādhyayanam] -ādhyāpanam K T M 9 adhyāpanaṃ] adhyayanaṃ K T M 12 samara] sadamara B a.c. N G K T M $\|$ anucitaṃ] ucitaṃ B G; nucitaṃ N a.c.; nocitạ̣ N p.c. 18 bhṛguh]] guruh K T M

1 prayojanam ... nirūpaṇam] NS $1.5 \quad 4-7$ adhyetavyam ... ca] VS $1.7 \quad 11$ na ... api] BhP 3.28.53 16-19 sūryaḥ ... pravartakāḥ] KS 1.2-3

12 samarasiṃhādi] The $d a$ in $\mathrm{N}$ shows signs of having been rubbed at or coloured over. 
The purpose is to ascertain the good and evil of the world.

And a person qualified for [learning] this science is one desirous of understanding the results of the year, [answers to] questions and so on; and only a Brahman. For Vasișțha says [in Vasișthasaṃhitā 1.7]:

Therefore this pure and secret science of the stars should be studied only by Brahmans, because having rightly understood this, one attains wealth, merit, liberation and outstanding renown.

Objection: even the study of the Tājika treatise composed by Yavanācārya, which consists of Persian words such as ikkavāla, ${ }^{5}$ is not [to be] undertaken; and the teaching [of it should be] avoided from afar. For it is said in Tradition [Bhavisyapurāna 3.28.53]:

One should not speak the Yavana language even when the [vital] breaths are in one's throat. ${ }^{6}$

It being founded on that [treatise], studying a treatise even by an author such as Samarasimha is improper, on the principle that if the foundation is impure, all is impure.

[In reply] to this it is said: Yavanācārya being enumerated among the eighteen authors of [astronomical] works, his words are authoritative. For Kaśyapa says [in Kaśyapasaṃhitā 1.2-3]:

Sūrya, ${ }^{7}$ Pitāmaha, ${ }^{8}$ Vyāsa, Vasișțha, Atri, Parāśara, Kaśyapa, Nārada, Garga, Marīci, Manu, Angiras, Lomaśa, Pauliśa, Cyavana, Yavana, Bhṛu, and Śaunaka: these eighteen are the propounders of astral science.

5 This statement shows that Balabhadra does not differentiate between Persian words proper and (Persianized) Arabic words such as iqbäl; cf. the Introduction.

6 That is, even in the face of death. I am grateful to S.R. Sarma for alerting me to this idiomatic expression, correctly understood by Weber (1853: 247), who renders it 'auch wenn's Einem ans Leben geht', though not by Pingree (1997: 87), who translates 'by breath that (accidentally) comes from one's throat'. Persian words could hardly be supposed to emanate 'accidentally' from the throat of a Brahman, and -gata in a compound typically signifies presence in, not emergence from (which would be more naturally expressed by $-u d g a t a$ ). For the varying meanings of the word yavana, see the Introduction.

7 That is, the sun conceived of as a deity; the sun god.

8 'The grandfather', that is, Brahmā the creator. 
tathā ca yavanācāryapraṇitaṃ saṃskṛtopanibaddham jātakaśāstram yavanajātakākhyam dṛśyate | tathaiva brahmaṇaḥ sakāśāt pāramparyavaśena tājikakartṛtvam apy asya smaryate | uktaṃ ca romakeṇa |

brahmaṇā gaditạ̣ bhānau bhānunā yavanāya yat | yavanena ca yat proktam tājikam tat prakāśitam || iti |

anye 'pi tājikācāryā uktāḥ ṭọ̣arānande |

khattakhutto romakaś ca hillājo dhișaṇāhvayaḥ| durmukhācārya ity ete tājikasya pravartakāh || iti | atha ca $\mid$ jyotihssástraphalam purānaganakair ādeśa ity ucyate | iti siddhāntasmaranāāt | tathā ca | kṛte paitāmahaṃ śāstraṃ tretāyām bādarāyaṇam | gārgīyaṃ dvāpare proktaṃ susatyaṃ tājikaṃ kalau \| iti jïrṇatājikokteḥ | atha ca | mlecchā hiyavanās teșu samyak śāstram idaṃ sthitam | rșivat te pi püjyante kim punar daivavid dvijah $\|$

10-11 purāṇa ... iti] purāṇair ādeśya ity ucyateti K T; purāṇakair ādeśyam ity ucyata iti M 10 jyotih ... ucyate] SŚ $18.6 \quad$ 15-16 mlecchā ... dvijaḥ] BS 2.14

7 hillājo] B inserts a character of unknown meaning in the middle of this word. 
Also, there is a treatise on genethlialogy authored by Yavanācārya, composed in Sanskrit and entitled Yavanajātaka. Likewise, his authorship of Tājika is accepted by tradition on account of the succession [of teachers] beginning with Brahmā. ${ }^{9}$ For Romaka says:

That which was related by Brahmā to the sun [god], by the sun to Yavana, and which is proclaimed by Yavana, is revealed as Tājika.

Other Tājika teachers, too, are described in the Tọ̣arānanda:

Khattakhutta, Romaka, Hillāja, Dhiṣaṇa, and Durmukhācārya: these are the propounders of Tājika.

Moreover, [as seen] from the precept of Siddhānta[śiromaṇi 18.6]:

The ancient astrologers say that prediction is the outcome of astral science.

- and likewise from the statement in the Jirṇatājika:

In the Kṛta [age], the teaching of Pitāmaha; in the Tretā, that of Bādarāyaṇa; in the Dvāpara, that of Garga is proclaimed; [and] in the Kali [age], the Tājika [teaching] is very true.

- and further, from the statement of Garga [as quoted in Bṛhatsaṃhitā 2.14]:

For the Yavanas are foreigners; [yet] this science is well established among them, and they are venerated like sages. How much more, [then], a twice-born astrologer!

9 The passive causative of $s m r$ 'remember' has the technical sense of 'being stated in the smrti', that is, in those traditional Hindu texts which, while carrying religious authority, are considered non-eternal and therefore secondary to the unauthored śruti. In the present context, Balabhadra is referring to astrological tradition rather than smrti in the more narrowly religious sense; but his choice of expression suggests a desire to blur this distinction to some degree - a task facilitated by his tracing the origins of Taajika teachings to deities and sages of Hindu mythology. 
iti gargokteś ca yavanajyotirgranthānām adhyayane dvijānāṃ na doṣaḥ | anyathā pan̉kodbhavakamalāder îśvarapūjādau tyāgaḥ syāt | tathā bhujañgaphaṇavartimaṇigrahaṇe anādaraḥ syāt | uktaṃ ca gaṇeśadaivajñaị̣ |

\section{brahmadveșituruṣkanirmitam idạ̣ tārt̄̄yikaṃ vartate}

śāstram yady api sad dvijair api tathāpy adhyetum arham bhavet |

yasmād yat sadasatphalam nigaditam satyam hi kim pañkaje

śañkā pañkabhavā tathā phaṇiphaṇotpanne maṇau dūṣaṇam || iti |

hillājena tu brahmaviṣnurudramukhanirgataśāpena yavanatām prāptena śrīsūryeṇaiva yavanaśāstrapranayanād dvijānām api sūryasiddhāntavad etadadhyayanam yuktam ity uktam |

\section{keśaviṣnumukhanirgataśāpān mlecchatādhigatatigmamarīceh | romakeṇa puri labdham aśeșaṃ tad dvijādibhir ato 'dhyayanìyam || iti |}

puri romakapattane | yadā tu tad eva prameyaṃ kenacit subuddhinā samarasiṃhādinā adhītatadīyajyotiḥsāstreṇa dṛ̣hhatarasaṃskārād atyaktasaṃjñāparibhāṣeṇa saṃskṛtaśabdair upanibaddham cet pațhyate tadā na ko 'pi doṣa iti jñeyam | na vaded yāvanīm bhạsạ̄m etad vacanaṃ tu yāvanīyakāvyālaṃkārādivișayakam iti siddhāntah ||

nanu sūryasiddhāntādigranthās tu śrautasmārtakarmavișayakāḥ | katham asya tājikaśāstrasya śrautasmārtakarmaviṣayakatvam | ucyate |

2 anyathā] atha K T M 3 grahane] graham K T 4 nirmitam] saṃbhavam K T M 9-10 vad etad] vat tad KTM 11 keśa] keśava KTM 12 romakeṇa] romake ca KTM \| dvijāaibhir] dvijātibhir KTM 13 puri] scripsi; purīB N G; pura KT; pure M || yadā tu] yakṣyatu BN Ga.c.; yadā ca KTM 14 adhīta] adhītaṃ KTM \| tadìya] tadīyaṃ KTM || atyakta] avyakta K T M 20 așțavarșaṃ] așțame varșe M \| upanayīta] scripsi; upanīyet B; upanīyeyet $\mathrm{N}$ a.c.; upanīyet (upanayet?) N p.c.; upanīyet G; upanīyayet K T; upanayet M

4-7 brahma ... dūṣaṇam] TBh $1.4 \quad$ 11-12 keśa ... 'dhyayanīyam] HD 1.6

20 așțavarșam ... upanayīta] This phrase occurs in ŚVK 1.88, 2.73, 4.19, seemingly as a quotation but with no attribution. 
- there is no fault in twice-borns studying Yavana books on astral science. Otherwise, one should reject lotus flowers springing from the mire and so on for the worship of the Lord and so on; and one should not endeavour to obtain jewels located in serpents' hoods. ${ }^{10}$ And this is said by Ganeśa Daivajña [in Tājikabhūṣaṇa 1.4]:

Although this science was created by Brahman-hating Turks and is Tataric, ${ }^{11}$ it is still fit to be studied even by the twice-born because the good and evil results predicted from it are true. In [enjoying] a lotus, is there any fear of the mire [from which it has grown], or is there any blemish in a jewel obtained from a serpent's hood?

But Hillāja says [in Hillājadīpikā 1.6] that because the Yavana science was founded by the illustrious sun [god] himself, who had become a Yavana due to a curse issued from the mouths of Brahmā, Viṣnu and Rudra, the study of this is proper even for the twice-born, like [the study of] the Süryasiddhānta:

Romaka received this whole [science] in the city from the sun [god], who, by a curse issued from the mouths of Brahmā, Siva and Viṣnu, had been turned into a foreigner; therefore, it is fit to be studied by the twice-born and so on.

'In the city' means in the city of Rome. And when that same subject matter is rendered in the Sanskrit language after very certain revision by an intelligent man like Samarasimha who has studied that sort of astrology, not neglecting the explanation of terminology, it should be understood that there is no fault at all in studying it. But the statement 'One should not speak the Yavana language' applies [only] to Yavana poetry, rhetoric and so forth: this is the conclusion.

Objection: but books such as the Süryasiddhānta deal with ritual actions prescribed by Revelation and Tradition. How does the Täjika science deal with ritual actions prescribed by Revelation and Tradition?

[In reply] it is said: by statements such as:

One should initiate a Brahman of eight years, [or] in the sixth [year], [if one] desires food and so on.

10 The analogy of the jewel refers to a so-called snake-stone, taken from the skull of a snake and believed to be effective as an antidote to snake venom.

11 Tārtīyika; see the Introduction. 
aștavarșā bhaved gaurī navavarșā ca rohiṇi |

\section{gaurị̣ dadad brahmalokaṃ sāvitraṃ rohiṇịn dadat |}

ityādibhir vākyair upanayanavivāhakālā aneke 'bhihitāḥ | teșāṃ jñānaṃ jhațiti tājikaśāstrād eva jāyate | anyac ca | uktakāle 'pi guruśuddhim vinā yathopanayanavivāhāv utsargato na bhavatas tathā janmakālāt tattadvarṣeșv ariștasambhave 'pi na bhavato dușțaphalasya tulyatvād iti ||

nanu sadasatphalāvabodhārtham asti tājikaśāstrasya pravṛttị̣ | tājikaśāstroktavarșapraveśo janmakālādhīnah | tadangīkāre ca jātakaśāstrād eva nụnāṃ sadasatphalabodho bhaviṣyati | kim anena tājikaśāstreṇa ||

atrocyate | jātakaśāstrāt sadasajjñānaṃ bahvāyāsasādhyạ̣ bahukālasādhyam cāsti | tathā hi janmakālīnaspașțagrahān angīkṛtya dṛștị̦aḍbaleșțakașțabalāni sarvagrahāṇām āyurvarșāni cānīya tato daśām antardaśâm ca nirṇiya jātakaśāstroditaṃ sadasatphalaṃ vācyam | tatrāpi ișțakaștabalāśrayaguṇakānayane sacchedagaṇitasya daśāpraveśe janmakālakaliyātavatsarasyetyādiganiitasya ca jñānaṃ siddhāntavidām eva na yādṛsāānām tādṛśānām ||

anyac ca | evam atyāyāsenānītāsv api daśāsu phalavivekah kartuṃ na śakyah | katham | āyụ̣ krtam yena hi yat tad eva ityādivarāhokter grahāyurvarṣāṇām daśa vā pañcadaśa vā viṃśatir vetyādīnāṃ bahūnāṃ varṣānāạm

2 dadad] dadyād B K T; dayāt N G $\|$ dadat] daded K T $\quad 3-4$ jhațiti] sad iti N 7 asti] asya T 9 nṛ̣āṃ sadasat] om. B N G a.c. 11 cāsti] scripsi; vāsti B N G; -tāsti K T; -tā’sti M 14 guṇakā-] gaṇakā- T

1 așțavarṣā ... rohinịi] PS $7.4 \quad 18$ āyuh ... ity] BJ 8.2

1 așțavarṣā ... rohin̄ī] VāP (s.v. upayama) attributes to Vyāsa a stanza nearly identical to PS 7.4. 2 gaurīm ... dadat] VāP (s.v. upayama) attributes a stanza beginning thus to Vātsya, supplying the verb prāpnoti. 
- and [Parāśarasmṛti 7.4]:

[A bride] of eight years is a gaurī, and one of nine years, a rohinī.

Giving away a gauri [one attains] the world of Brahmā; giving away a rohinī [one attains the world] of Savitr.

- many [possible] times are laid down for initiations and weddings. The knowledge of these arises instantly from the Täjika science itself. And further, just as an initiation and a wedding are not generally performed even at the time stated without an auspicious placement of Jupiter, neither are they performed when [signs of] misfortune arise in such-and-such a year from the time of birth, because the evil results are equal.

Objection: the purpose of employing the Tajika science is to ascertain good and evil results. [But] the revolution of years taught in the Tajjika science is dependent on the time of the nativity, and [so], in accepting it, men will understand good and evil results from the science of genethlialogy itself. What, [then], is the use of this Tajjika science?

[In reply] to this it is said: the knowledge of good and evil is found from the science of genethlialogy with much effort and over long time. Likewise, the good and evil results arising from the science of genethlialogy are to be pronounced after establishing the true [places of the] planets at the time of the nativity; calculating the aspects, the six strengths, the strengths for good and evil, and the years of life of all the planets; and deriving the periods and subperiods from them. ${ }^{12}$ And there, too, the knowledge of computation [necessary] in calculating the multipliers involved in the strengths for good and evil, along with the divisors, and of the computation of the years elapsed in the Kali [era] at the time of birth [necessary] in [calculating] the beginning of a period, and so forth, belongs only to experts in the system, not to just anyone.

And further, when the periods have thus been calculated with the utmost effort, it is still impossible to determine the results. - How so? - As [we see] from the statement of Varāha[mihira in Brhajjātaka 8.2]: 'That [amount of] life which is granted by any [planet]', and so on, that the planets may [grant] many years of life - ten or fifteen or twenty, and so forth - it is not possible

12 The daśa or chronocrator system alluded to by Balabhadra, commonly known as mūladaśa , is treated for instance in adhyāya 8 of the Brhajjātaka, and in adhyāya 8 of the Jātakakarmapaddhati (or Śrīpatipaddhati). 
sattvāt tattadgrahasambandhi subhāśubhadaśāphalam tāvatkālamadhye naikarūpaṃ sambhavati | antardaśāyām api varșānāạm pañcakaṃ șațkaṃ vā ekaikasya samāyāti | tatrāpi naikarūpam antardaśāphalam | vidaśāsūpadaśāsu ca kasyacid alpavarṣatvaṃ kasyacid bahuvarșatvam samāyāti | tatrāpi naikarūpaphalatā vaktuṃ śakyā | tasmād bahvāyāsenāpi jātakaphalaṃ sthūlakālaphaladam asti | tājike tu varșamadhye sarveșām grahāṇām daśāḥ samāyānti | antardaśāsv alpadinādyāḥ samāyānti | tatrāpi māsapraveśadinapraveśadaśāphalam atyantam sūkṣmataraṃ samāyāti | atạ̣ sadasatphalajñānaṃ tājikaśāstrād eva nitāntaṃ kāntam | uktaṃ ca samarasimhena|

prāyo na jātakaphale ciraprayojye matih sphurati puṃsām | tenātra hāyanaphalam prakāśyate tājikaproktam || iti |

nanu prācīnakarmarūpasya daivasya avaśyambhāvitvāt katham udyamo varṣaphalavicārasya | yad āha śaunakạ̣ |

yena tu yat prāptavyaṃ tasya vidhānam sureśasacivo 'pi yah sākșān niyatijñah so 'pi na śakyo 'nyathā kartum || iti |

tathā ca daivasya balavattve puruṣakāro nirarthaka iti || atrāhuh kị̣ ca yadi daivam eva phalet tadā kṛṣyādyupāyeșu puruṣakārarūpā pravṛttir na syāt | atha ca śrutismṛtyāveditavidhiniședhāś ca nirarthakāḥ syuḥ | tad āha keśavārkaḥ |

7 dinādyāḥ samāyānti] scripsi; dinādyā samāyāti B N G K T M $\|$ tatrāpi] tatra K T M 8 dinapraveśadaśā] om. K M 11 cira] kāla add. K M 12 tājika] jātaka K M 17 ca] om. K T M || puruṣakāro] purușākāro K T 18 ca] om. K T M \| phalet] phalan K T; phalaṃ M 18-19 puruṣakāra] purușākāra K T

11 ciraprayojye] $\mathrm{T}$ displays a hiatus, wide enough for two characters but containing only the horizontal top stroke of the Devanāgarī script, between cira and prayojye. 
that the good or evil results of the period related to this or that planet should remain the same throughout that time. Even the subperiod of each planet may last for five or six years, and so the results of the subperiods cannot remain the same either; and in the third- and fourth-level periods, that of one [planet] lasts for few years, that of another for several years. Even there, it is not possible to predict the same results. Therefore, the results of genethlialogy, although [derived] with great effort, result [only] in broad times. ${ }^{13}$ But in Tājika, the periods of all the planets occur within a year. A subperiod lasts [only] a few days; and the results of the periods in a monthly revolution or daily revolution become even more exceedingly accurate. Therefore, only the knowledge of good and evil results [derived] from the Tājika science is extremely pleasing. And Samarasiṃha says [in the Tãjikaśāstra]:

In general, [true] understanding does not shine forth for men in [considering] the results of genethlialogy, which are applied to long [times]. Therefore, the annual results proclaimed by the Täjikas are elucidated here.

\subsection{Fate, Human Effort, and the Astrologer}

Objection: but since fate in the form of [the results of] previous action must inevitably come to be, why bother with considering the results of the year? As Śaunaka says:

Whatever anyone is to meet with, not even the counsellor of the lord of gods, who has direct knowledge of destiny, is able to alter his fate.

And fate thus being powerful, human effort is meaningless.

To this they reply, firstly: if fate alone were to give results, then one would not have to engage in human effort by pursuits like ploughing and so forth. Moreover, the injunctions and prohibitions laid down by Revelation and Tradition would be meaningless. Thus says Keśavārka [in Vivāhavrndāvana 14.4]:

$13[T]$ he results $[\ldots]$ result: the tautology is in the original. 
phaled yadi prāktanam eva tat kim krșyādyupāyeșu parah prayatnaḥ | śrutih smṛtiś cāpi nṛnām niṣedhavidhyātmake karmaṇi kiṃ niṣaṇnā || iti |

api ca janmāntarārjitaṃ daivam api puruṣakāraṃ vinā na ghațata iti purușārthasyaiva mukhyatvam | tathā ca vasantarājaḥ |

pūrvajanmajanitam purāvidạ̣ karma daivam iti sampracakșate | udyamena tadupāriitaṃ tadā vāñchitam phalati naiva kevalam || iti |

atha purușārthasyaiva mukhyatvāngīkāre

avaśyaṃbhāvibhāvānāṃ pratīkāro bhaved yadi | tadā duḥkhair na bādhyeran nalarāmayudhiș̣thirāḥ $\|$

nābhuktạ̣ kṣīyate karma kalpakoțiśatair api | avaśyam eva bhoktavyaṃ krtaṃ karma śubhāśubham \|

ityādivākyānāṃ kā gatir iti ced atrocyate | atha karmaṇāṃ vaicitryaṃ kānicid dṛ̣hhamūlāni kānicic chithilamūlāni | yatra janmapattraśakunavarṣapraśnādibhir daśāphalarūpeṇa pratibandhakena saṃtānavidyādyabhāvo nirṇìtas tatra grahaśāntyādirūpeṇa pūrṇaprayatnenāpi saṃtānādiprati15 bandhakībhūtaṃ duritạ̣ dṛ̣hhamūlatvān nivārayituṃ na śakyate | yatra tu grahacāravaśena gocarādinā saṃtānādipratibandho nirṇitas tac chithilamūlatvena svastyayanādinotpādyam | uktaṃ ca smṛtau |

hanyate durbalaṃ daivaṃ pauruṣeṇa vipaścitā | iti |

\footnotetext{
1 phaled] phale K T M 2 kiṃ niṣaṇṇā || iti] kiṃ niṣam iti N a.c.; kiṃ niṣaṇam iti N p.c.; kinniședhati M 3 purușakāraṃ] purușākāraṃ K T $\quad 5$ daivam] devam B N G 6 naiva] caiva N G 12 atha] tatra K T M 13 pattra] patre N; yatra T 14 pratibandhakena] pratibandhe kena N \|| vidyādyabhāvo] vidyādyabhāve B; vidyāpabhāvo N 15 pūrṇa] om. K T M 16 duritaṃ] om. K T M 18 mūlatvena] bhūtatvena K T M
}

1-2 phaled ... niṣaṇnāa $]$ VV 14.4 $\quad 5^{-6}$ pūrva ... kevalam] ŚA $1.22 \quad$ 8-9 avaśyaṃ ... yudhișțhirāḥ] GPS 11.8; PD 7.156 10-11 nābhuktam ... śubhāśubham] NP 1.31.69 
If only previous [action] bears fruit, then why [expend] great effort in ploughing and other pursuits? And why should Revelation and Tradition alike be devoted to [describing] forbidden and enjoined acts?

Moreover, the fate earned in other births will not take effect without human effort. Thus the pre-eminence of human endeavour [is established]. And so [says] Vasantarāja [in Śakunārṇava 1.22]:

Knowers of the past declare fate to be action produced in previous births. The desired [result] that was earned then will bear fruit by effort, not by itself.

Now, if [it is asked] what is to be made of statements such as [Garudapurāṇasāroddhāra 11.8 and Nāradapurāṇa 1.31.69]:

If states that will inevitably come to be could be counteracted, then Nala, Rāma and Yudhișthira would not have been afflicted with misery.

Action [the result of] which has not been experienced will not vanish even in billions of aeons. [The result of] action performed, good or evil, must inevitably be experienced.

- if the pre-eminence of human endeavour alone is accepted, [in reply] to this it is said that actions are manifold, some being firmly rooted and others, loosely rooted. When, from the figure of the nativity, omens, annual [revolutions], questions ${ }^{14}$ and so on, [misfortune] such as the absence of progeny or learning is ascertained due to an obstruction in the form of the effect of a [planetary] period, then it is not possible to avert the evil that is obstructing progeny and so on even by the utmost effort in the form of propitiation of the planets and so on, because it is firmly rooted. But when an obstacle to [the attainment of] progeny and so on is ascertained by the movements of the planets in transit and so on, that [desired object] may be produced by benedictions and so on, because [the obstacle] is loosely rooted. For it is said in Tradition:

Weak fate is struck down by intelligent effort.

14 That is, from a horoscope cast for the time and place of the question itself. 
evaṃ śubhasūcakadaśāpākakāle kriyamāṇā yātrā vināyāsena phalasādhikā aśubhadaśāyāṃ hānidety ato 'vaśyam jyotiḥsaāstragaṇanopayogạ̣ | pūrvoktaśaunakādivākyāni dṛ̣hamūlakarmaviṣayakāni | daivapuruṣakārayoḥ sācivyam uktaṃ yājñavalkyena |

yathā hy ekena cakrena rathasya na gatir bhavet

evaṃ purușakāreṇa vinā daivaṃ na sidhyati || iti |

saṃkṣepāj jyotiḥsāâstrādhyayane phalam āha māṇụavyah |

evaṃvidhasya śrutinetraśāstrasvarūpabhartuh khalu darśanaṃ vai |

nihanty aśeșam kaluṣam janānām șaḍabdajam dharmasukhāspadam syāt ||

sūryasiddhānte 'pi |

divyam cakṣur graharkșānāạn darśitam jñāanam uttamam |

vijñāyārkādilokeșu sthānaṃ prāpnoti śāśvatam || iti |

jñānaviśeșeṇa jyotirvidạ̣ pūjātāratamyaṃ jīrṇair abhyadhāyi |

daśadinakṛtapāpaṃ hanti siddhāntavettā

tridinajanitadoșam tantravid drșța eva |

karanabhagaṇavettā hanty ahorātradoșam

janayati ghanam añghas tatra nakșatrasūcī || iti |

nakṣatrasūcilakṣaṇaṃ vārāhasaṃhitāyām |

1 yātrā vināyāsena] yātrāpy anāyāsena M $\quad 5$ na] tu B N G a.c. $\quad 7$-ādhyayane] -ādhyāpane K T M 9 kaluṣaṃ janānāṃ] kaluṣajjanānāṃ K T $\|$ abdajaṃ] abdatan K; abdato M $\quad 15$ tantravid dṛșta] taṃtamaṃhovidașta B; taṃtratamaṃhovid dṛșta $\mathrm{N}$ a.c.; taṃtamaṃhovid dṛșța G a.c. 16 vettā] haghanamam add. N a.c. G a.c. \| hanty] haghanamaṃhaty B 17 ghanam anghas] ca ghamoghas B; ca ghamaughas $\mathrm{N}$ a.c. $\mathrm{G}$; ca ghanam amghas $\mathrm{N}$ p.c.; ghanam amphas M

5-6 yathā ... sidhyati] YS 1.351 11-12 divyaṃ ... śāśvatam] SūS 14.23 
Thus, a journey undertaken at the time of maturation of a period indicating good [results] will bear fruit without effort, [whereas a journey undertaken] during an evil period will lead to failure. Thus, astrological calculation is necessarily useful. The utterances of Śaunaka and others quoted above refer [only] to [the results of] firmly rooted actions. That fate and human effort go hand in hand is stated by Yājñavalkya [in Yãjñavalkyasmṛti 1.351]:

For as a cart will not move on one wheel, so without human effort, fate does not take effect.

Māṇḍavya summarizes the results of studying the astral science:

The mere beholding of such a one who has mastered the essence of the science that is the eye of Revelation completely eradicates the impurities of men accrued over six years. [He] becomes the abode of righteousness and happiness.

And in Süryasiddhānta [14.23 it is said]:

Having understood the sublime knowledge shown [here], a divine eye [to perceive] the planets and stars, one attains an everlasting place among the sun and other [celestials].

The relative reverence due to an astrologer according to his particular knowledge was set forth by the ancients:

A knower of the [complete] system destroys evils committed for ten days on mere sight; a knower of the [basic] theory [destroys] blemishes accrued over three days; a knower of [abridged] manuals and of [the times of revolutions of the planets through] the zodiac destroys the blemishes of a day and night; but a [mere] stargazer generates a mass of sin.

The characteristics of a stargazer [are stated] in Varāha[mihira's Brinat]saṃhitā [2.16]: 
aviditvaiva yaḥ śāstram daivajñatvam prapadyate | sa pañktidūṣakah pāpo jñeyo nakșatrasūcakaḥ \|

tithyutpattimn na jānanti grahāṇām naiva sādhanam | paravākyena vartante te vai nakșatrasūcakāḥ || iti |

śrāddhe gaṇakānām apāṅkteyatvaṃ dharmaśāstroktam nakṣatrasūcakā- $\quad 5$ bhiprāyeṇa jñeyam | uktaṃ ca vasișthena |

triskandhapāramgama eva pūjyah śrāddhe sadā bhūsuravrndamadhye | nakșatrasūcī khalu pāparūpo heyaḥ sadā sarvasudharmakrtye || iti |

nanv asmin granthe granthabāhulyam eva dūṣaṇam iti cen na | yato granthasaṃkṣepe anyagranthāpekṣā vicārasaṃśayaś ca bhavati | grantha10 vistāre saṃśayāpekṣayor abhāvo bhavati | tasmād granthavistāro na doṣāyeti jñeyam | uktạ̣ ca yādavena |

saṃkșepe saṃśayāpekșe śrotuh syātām asamśayam | varīyān vistaras tasmād apekșāsaṃśayāpahaḥ || iti |

3 utpattiṃ] utpannaṃ B N G 4 iti] om. K T M $\quad 5$ śāstroktam ] śāstre K T M 10 saṃśayaś] saṃkṣayaś G a.c.

1-2 aviditvaiva ... nakșatrasūcakah] BS 2.16 7-8 triskandha ... kṛtye] VS 1.10 13-14 samkṣepe ... saṃśayāpahạ]] TYS 1.8

3-4 tithy ... sūcakāh] This stanza is not found in available editions of the BS. PDh 1.2, apparently Balabhadra's immediate but unacknowledged source, separates it from the preceding one with the words anyac ca, suggesting a different but unnamed source. 
He who assumes the role of astrologer without knowing the science should be known as a wretched defiler of the row, ${ }^{15} \mathrm{a}$ [mere] gazer at the stars.

[And another source states:]

They do no know how to derive a lunar date, nor how to find [the places of] the planets. They depend on the words of others: those are the gazers at the stars.

The inadmissibility of astrologers at a śräddha ${ }^{16}$ declared in sacred law should be understood as referring [only] to stargazers. For Vasișțha says [in Vasișthasaṃhitā 1.10]:

One who has mastered the three branches [of astral science] is always to be honoured among Brahmans gathered at a śrāddha; but a stargazer is of evil nature and should be shunned at all pious functions.

If it should be objected that the abundance of books [cited] in this book is a fault, [we say]: not so, for when a book is abridged, the need for other books and doubts on the deliberations [presented in it] result. When a book is expanded, freedom from [such] need and doubt results; therefore one should not consider the extensiveness of a book as a defect. For Yādava says [in Tājikayogasudhānidhi 1.8]:

In abridging, doubt and need undoubtedly arise in the hearer: therefore, extensiveness, which removes need and doubt, is better. ${ }^{17}$

\footnotetext{
15 The 'row' (pankti) is that of Brahmans seated in order for a meal, an assembly into which no ritually defiling person may be admitted.

16 Śräddha is an annual observance in honour of the ancestors. Like all important rituals, it is incomplete without the feeding of priests and other honoured guests.

17 The fact that Balabhadra considers this defence necessary illustrates the value that Indian learned traditions have placed on conciseness of expression, a value directly related to the prevalence of oral transmission and rote learning - hence the use of 'hearer' where we might expect 'reader'.
} 
alam atiprasangena | prakṛtaṃ tāvad anusarāmaḥ || athāto rāśisvarūpam | tatroktạ̣ vāmanatājike |

phalaṃ rāśigrahādhīnaṃ sarveșām prāṇinām yataḥ|

ato meșādirāsínām svarūpaṃ prān nirūpyate \| meșo vrșo 'tha mithunam karkạ siṃho 'tha kanyakā|

tulà tato vrśsikaś ca dhanur makara eva ca। kumbho mina iti proktā budhair dvādaśa rāśayaḥ $\|$ meșo 'tha mithunam siṃas tulā dhanur atho ghatah | vijñeyā vibudhair ete krürāḥ șad api rāśayah || vrșah karkas tathā kanyā vrśsciko makaras tathā| mina ete șaḍ api ca vijñeyāh saumyarāśayaḥ \| pumsamiñãa rāśayah krūrāḥ strīsaṃñāḥ saumyarāśayaḥ \| meșakarkāv atha tulā makaraś cararāśayaḥ| vrșasiṃhau vrściko 'tha kumbhaś ca sthirarāśayaḥ| mithunam kanyakā dhanvī minaś ca dvisvabhāvakāh \| meșo 'tha vrșabhah siṃho 'parārdham dhanuṣas tathā | makaraś ca budhair jñeyā rāśayo 'mī catușpadāh \| karkațo vrśsikaś cobhau bahupādau prakīrtitau | kumbhamin̄āv ubhau rāśi vijñeyau pādavarjitau \| mithunaś ca tulā kanyā pūrvārdho dhanușas tathā | rāśayo dvipadāḥ proktā yavanācāryasūribhị̣ \| meșaś ca siṃhadhanuṣau vijñ̃eyā vahnirāśayaḥ| vrșaḥ kanyātha makarah syur ete bhūmirāśayah $\|$ mithunaś ca tulā kumbho rāśayah pavanātmakāḥ| karkavrścikamināśs ca vijñeyā jalarāśayah \| ardhaśabdā mrgạ̣ kumbhaḥ kanyā ete ca rāśayaḥ | tulālikarkaminnāś ca vijñ̃eyāḥ śabdavarjitāḥ| meșo vrșo 'tha mithunam siṃhah śabdānvito dhanuh $\|$ karkāliminā bahvapatyā jitmokșaghațakāh smrtāḥ | madhyāh sị̣hainakanyājatulācāpās tathālpakāḥ \|

1 anusarāmaḥ] anusaromaḥ B G a.c.; anusaroma N a.c. $\quad 2$ athāto] atha K T M \|t tatroktaṃ] uktam ca $\mathrm{K}$ T; uktac ca M 3 yatah] om. $\mathrm{N} \quad 12$ pumsaṃjñā ... saumyarāśayaḥ] om. K T a.c. M 13 karkāv] kanyārkāv B a.c. $\quad 30$ madhyāḥ ... tathālpakāḥ] madhyeṇasiṃhakanyājatulācāpolpasūtayaḥ B G; meṃdhyeṇasiṃhakanyājatulācāpolpasūtayaḥ N

29 karkālimīnā bahvapatyā] All witnesses agree on this unmetrical reading. 


\subsection{The Signs of the Zodiac}

But enough of digression: let us now pursue our main topic. And first, the natures of the zodiacal signs. On this matter, it is said in the Vāmanatājika:

As the results [accruing] to all creatures depend on the zodiacal signs and planets, the natures of the signs beginning with Aries are described first. The twelve signs are said by the wise to be Aries, Taurus, Gemini, Cancer, Leo, Virgo, Libra, Scorpio, Sagittarius, Capricorn, Aquarius and Pisces.

Aries, Gemini, Leo, Libra, Sagittarius and Aquarius are known by the learned as the six fierce signs, and Taurus, Cancer, Virgo, Scorpio, Capricorn and Pisces are known as the six gentle signs. The fierce signs are known as male; the gentle signs are known as female.

Aries, Cancer, Libra and Capricorn are movable signs; Taurus, Leo, Scorpio and Aquarius are fixed signs; Gemini, Virgo, Sagittarius and Pisces are of a dual nature.

Aries, Taurus, Leo, the latter half of Sagittarius, and Capricorn: these signs are known by the learned as having four feet. Cancer and Scorpio are both said to have many feet. Both the signs Aquarius and Pisces are known as having no feet. The signs Gemini, Libra, Virgo and the former half of Sagittarius are said by the sage Yavanācārya ${ }^{18}$ to have two feet.

Aries, Leo and Sagittarius are known as fiery signs; Taurus, Virgo and Capricorn are earthy signs; Gemini, Libra and Aquarius are airy signs; Cancer, Scorpio and Pisces are known as watery signs.

Capricorn, Aquarius and Virgo have half a voice; Libra, Scorpio, Cancer and Pisces are known to have no voice; Aries, Taurus, Gemini, Leo and Sagittarius have a voice.

Cancer, Scorpio and Pisces have much progeny; Gemini, Taurus and Aquarius are said to be middling; and Leo, Capricorn, Virgo, Aries, Libra and Sagittarius, to have few.

18 As this name or epithet is in the plural, an alternative translation would be by the sagely Yavana teachers'. 
rūkșāḥ siṃhadhanurmeșāḥ pītoṣnạhḥ pittadhātavaḥ|

vrṣakanyāmrgā rūkșā uṣnaśittāś ca vātulāh \|

yugmakumbhatulā uṣnāḥ snigdhānggās tulyadhātavaḥ|

karkaminālayah snigdhāh śittāś ca śleșmadhātavaḥ \|

nrpavițśüdrabhūdevās tathā pūrvādikā diśạ |

meșāt trih parivartena vijñeyā vibudhaih sadā $\|$

prșțhodayāh karkamrgadhanurmeșavrșā amī|

śeșāḥ śîrșodayā jñeyā ubhayaś ca jhașạ̣ smṛtah \|

śřrșodayā dinabalāḥ śeșā rātribalāh smṛtāh |

rāśeh svanandabhāgo yah sa tu vargottamāhvayaḥ || iti |

atha rāśivarṇān āha samarasiṃhaḥ |

arunasitaharitapāțaladhūsaravipāṇdurā vicitrah |

śitihemadyutipingāḥ karburababhrū hy ajādivarṇāh syuḥ || iti |

atha rāśișu viṣamodayatvasamodayatvam uktaṃ samarasiṃhenaiva |

vișamodayā mrgādyāh șad ḍhrasvatvena kālamānasya |

karkādyāh șad dịrghatvāt samodayā ajatule ca samāne \|

1 rūkṣāḥ] sūkṣmāh K T M $\quad 3^{-4}$ tulyadhātavah ... ca] om. B N G 9 dinabalāḥ] dinacalāḥ N G 12 vipāṇ̣̣urā vicitraḥ] scripsi; vipāṇḍuravicitrāḥ B N G K T; truṭpāṇḍuravicitrāḥ G p.c.; viṭpāṃụuravicitrāḥ M 14-100.8 atha ... iti] om. B N G a.c.

12-13 aruṇa ... syuh] Cf. LJ 1.6

16 dīrghatvāt ... samāne] Although this part of the stanza is unmetrical, there is nothing on which to base an emendation.

19 We see here a reworking of Graeco-Arabic four-humour medical theory adapted to the classical Āyurvedic terminology comprising three humours $($ doșa $)$ : the fiery signs are dry, very hot, and correspond to bile; the earthy signs are dry, somewhat cooler, and correspond to wind (replacing the Graeco-Arabic humour of black bile); the airy signs are moist, hot, and correspond to a mixture of humours (to make up for the missing humour of blood); while the watery signs are moist, cool, and correspond to phlegm.

20 That is, east, south, west, north.

21 Although several of the colour terms used in this stanza have more than one meaning, comparison with the parallel passage in Samarasiṃha's Karmaprakāśa 1.7 makes the meanings given here more certain. 
Leo, Sagittarius and Aries are dry, yellow-hot, of bilious temperament; Taurus, Virgo and Capricorn are dry, hot and cool, of windy temperament; Gemini, Aquarius and Libra are hot, moist of body, of equally mixed temperament; Cancer, Pisces and Scorpio are moist, cool, of phlegmatic temperament. ${ }^{19}$

[The four signs reckoned] by repetition thrice over from Aries are ever known to the learned as princes, commoners, menials and Brahmans, [respectively], and as the directions beginning with the east. ${ }^{20}$

Cancer, Capricorn, Sagittarius, Aries, Taurus: these rise with their hinder parts. The rest are known to rise with their heads. Pisces is said to do both. Those rising with their heads are strong in the daytime; the others are said to be strong at night.

The own ninth-part of a sign is called the best of its class.

Next, Samarasimha states the colours of the signs [in the Täjikaśāstra]:

Red, white, green, pink, grey, whitish, many-coloured, black, golden, yellow, variegated, and brown are the colours of [the twelve signs] beginning with Aries. ${ }^{21}$

Then, Samarasiṃha himself describes [in the Tājikaśāstra] which among the signs rise crookedly or evenly: ${ }^{22}$

The six [signs] beginning with Capricorn rise crookedly because [their] measure of time is short; the six beginning with Cancer rise evenly because [theirs] is long; [the six signs beginning with] Aries and Libra, [respectively], are equal. ${ }^{23}$

22 Although no zodiacal sign rises completely perpendicular to the horizon even at the terrestrial equator, as the ecliptic (and therefore the band of the zodiac) is inclined to the celestial equator, for places of observation further north or south, the signs with longer ascensional times rise in a more upright fashion than those with shorter ascensional times.

23 While the metrical deficiency of the final quarter-stanza suggests some corruption, the translation given is the most likely meaning. The verse as a whole, as well as Balabhadra's explication of it, can only refer to the tropical zodiac, although this is not explicitly stated. In that zodiac, the six signs from Capricorn to Gemini rise in a shorter time than the average two hours per sign, while the remaining six signs take more than two hours each to rise. Aries and Libra themselves do not share the same rising time, as Aries shares the shortest rising time of all with Pisces, whereas Libra shares the longest with Virgo. However, the two halves of the zodiac beginning with Aries and Libra, respectively, do correspond exactly in terms of rising times. 
yady api svalpākṣabhede 'ṃśe kālasya hrasvadīrghatvam na sambhavati tathāpi bahvakṣabhede 'ṃśe tat sambhavaty eva | tad yathā | yatrākṣabhā dvādaśāngulās tatra makarādīnām udayapalāni ma 283 kuṃ 203 mī 158 me 158 vṛ 203 mi 283 karkādīnām udayapalāni ca ka 363 siṃ 395 kạ̣ 398 tu 398 vṛ 395 dha 363 | atra makarāditah karkādīnām udayapalāni bahvadhikānīti jñeyam | eșāṃ prayojanam āha samarasiṃha eva |

\section{brhatāṃ samodayānām rāśīnām madhyago vidhur vṛddhim | yadi yāti tadā vṛddhir varșe syād vyatyayād dhāniḥ || iti |}

meșādirāśīnāṃ saṃjñāntaram uktaṃ varāheṇa |

kriyatāvurïitumakulīraleyapāthonajūkakaurpyākhyāḥ |

taukșika ākokero hrdrogaś cāntyabham cettham \|

kendrādisaṃjñā uktās tenaiva |

kaṇțakakendracatuștayasaṃjñā lagnāstadaśamacaturthānām | saṃjñā paratah paṇapharam āpoklimasaṃñitạ̣ ca tatparatah $\|$

8 vṛddhir ... syād] vṛddhivaișamyaṃ M 13 kaṇțaka] kaṃțakā $\mathrm{B}$ a.c. $\mathrm{N}$ a.c. $\|$ daśama] daśa B G a.c.; śede N; dādaśa K T

10-11 kriya ... cettham] BJ $1.8 \quad$ 13-14 kaṇțaka ... tatparatạ] LJ 1.18

13 kaṇțaka ... samjjñā] The form of this pāda given by all witnesses, in dodhaka metre rather than $\bar{a} r y \bar{a}$, is taken from BJ 1.17 by the same author; LJ 1.18a should properly read kendracatustayakanțaka-. Either Balabhadra or an early copyist appears to have conflated the two stanzas, which are similar in both subject and composition.

24 Balabhadra is referring to the sun's equinoctial shadow $(a k s ̦ a b h \bar{a})$, measured at noon on the equinox using a standardized gnomon (śanku) 12 digits (angula) high. A midday shadow of the same length thus implies a solar elevation angle of exactly $45^{\circ}$, the gnomon and its shadow forming two equal sides of a right triangle. This angle subtracted from $90^{\circ}$ gives $45^{\circ}$ as the terrestrial latitude of the place of observation. (Where the two sides are of unequal length, the terrestrial latitude may be found by the formula $90-\tan ^{-1}(12 / s)$, where $s$ is the length of the shadow.) I am indebted to S.R. Sarma for explaining the details of this Sanskrit convention. Assuming a tropical zodiac, the figures given by Balabhadra do match a terrestrial latitude of $45^{\circ}$ north (about as far distant from the equator as Turin in Italy). It seems safe to assume that Balabhadra calculated this example theoretically, without reference to any place known to him personally. A pala is approximately 24 seconds of clock time.

25 The first eleven of these are Sanskritized Greek names: Kriya from Kpı́s; Tāvuri from

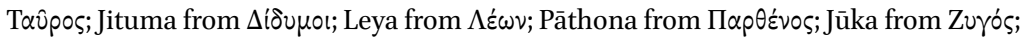

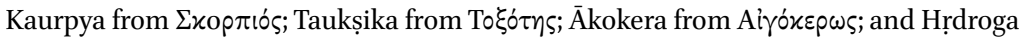


Although the time cannot become [very] short or long when the degree of latitude is small, it does become so when the degree of latitude is great. For example, where the shadow of latitude is twelve digits, ${ }^{24}$ the rising [times in] palas of the [six signs] beginning with Capricorn are:

$\begin{array}{llllll}\text { Ca[pricorn] } & \text { Aq[uarius] } & \text { Pi[sces] } & \text { Ar[ies] } & \text { Ta[urus }] & \text { Ge[mini] } \\ 283 & 203 & 15^{8} & 15^{8} & 203 & 283\end{array}$

And the rising [times in] palas of the [six signs] beginning with Cancer are:

$\begin{array}{llllll}\text { Ca[ncer] } & \text { Le[o] } & \text { Vi[rgo] } & \text { Li[bra] } & \text { Sc[orpio] } & \text { Sa[gittarius] } \\ 363 & 395 & 398 & 398 & 395 & 363\end{array}$

From this it can be understood that the rising times of [the signs] beginning with Cancer are much greater than [those] of [the signs] beginning with Capricorn. [In the Tãjikaśāstra], Samarasiṃha himself states the purpose of these [categories]:

If the moon is increasing within the expansive signs that rise evenly, then there is increase in that year; if the reverse, decrease.

Varāha[mihira] gives synonyms of the signs starting with Aries [in Brihajjātaka 1.8]:

Kriya, Tāvuri, Jituma, Kulīra, Leya, Pāthona, Jūka, Kaurpya, Taukșika, Ākokera, Hṛdroga and Antyabha. ${ }^{25}$

He himself states the designations of the angles and other [places, in Laghujātaka 1.18]:

For [the places] following the ascendant, descendant, tenth and fourth [places, which are called] angles, quadrants or cardines, the designation is 'succedent', and [the places] following those are designated 'cadent'. ${ }^{26}$

from 'Yôpoxóos. Antyabha means simply 'the last sign'; however, antya could possibly be a pseudo-etymologized form of 'I $\chi \theta \dot{\varepsilon} \varepsilon \varsigma$.

26 Kendra, panaphara and āpoklima are all Sanskritized Greek technical terms: $\chi \dot{\varepsilon} v \tau$ pov,

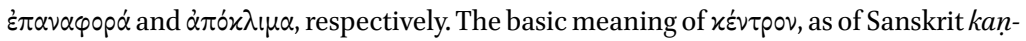
taka, is 'sharp point, goad'. The translation follows the received text of Laghujātaka 1.18a rather than the confused version of the text witnesses. 
grahāṇāṃ mūlatrikoṇag̣̣hāṇi tenaivoktāni |

siṃho vṛsaḥ prathamaṣașțhahayāngatauli-

kumbhās trikonabhavanāni bhavanti sūryāt | iti ||

iti rāśisvarūpam ||

atha rāśisvarūpaprayojanam | tatra dvipadacatuṣpadadinarātrisamjñ̃arāśiprayojanaṃ vakṣyamāṇabhāvaphale jñeyam | puṃstrīrāśiprayojanaṃ puṃkhețāh puṃrāśau strīgrahāh strīrāśau balinah iti sthānabale jñeyam | pittoṣnaśítādiprayojanaṃ rogakartā yatra rāśau ityādi șașțhabhāve rogasthitijñānārtham | rāśidikprayojanaṃ yātrāyāṃ digjñānārtham | cararāśyādiprayojanam carodaye bhojanam ekavāram ityādi bhojanavicāre jñeyam | rāśīnāṃ jalādicāritvaprayojanam tv ākhețake jalākhețam āhuh saviryair graharkșair jalākhyaih ity atra jñeyam | vahnyādirāśiprayojanam aștamabhāve śikhirāśau vahnibhayam ityādisthale jñeyam | brāhmaṇādijātikrūrasaumyatvādiprayojanaṃ lagnānumānavaśato vayah pramānạ̣ ca jātayo jñeyāḥ ityādi samarasiṃhoktạ̣ jñeyam | yathā mamāsmin varṣe kena lābho bhaviṣyatīiti vicāre lābhabhāvalagnasamavarṇena tatkrūra-

4 iti rāśisvarūpam ||] om. B N G 5 saṃjña] scripsi; saṃjñā B N G K T M 6 rāśi $\left.{ }^{1}\right]$ svarūpa add. K T M || vakṣyamāṇa] vasyamatā B N G || bhāvaphale] bhāvabale B N G 7 puṃrāśau] balinah add. K M; babalinaḥ add. T 8 ityādi ... roga] ityādiṣabhāveviṃroga K; ityādiṣv abhāve viroga $\mathrm{M} \quad 9$ dik] tridiva B N; diva B a.c. G 11 jalādi] calādi T 13 bhāve] bhāge B N a.c. G

2-3 siṃho ... sūryāt] BJ $1.14 \quad 8$ roga ... rāśau] VT 10.15 10 carodaye ... ekavāram] Cf. PV 14.2; TYS $16.18 \quad$ 11-12 jalākhețam ... jalākhyaiḥ] VT 18.34 
He also states the mülatrikona ${ }^{27}$ houses of the planets [in Brihajjātaka 1.14]:

Leo, Taurus, the first [or Aries], the sixth [or Virgo], Sagittarius, Libra and Aquarius are the trikona houses [of the planets reckoned] from the sun. $^{28}$

This concludes the natures of the zodiacal signs.

Next, the purpose of [knowing] the natures of those signs. Concerning this, the purpose of the signs designated as having two feet or four feet, [belonging to] day or night, should be understood to relate to the results of the places, which will be described below. The purpose of [designating] the signs male or female should be understood to relate to strength by position, as in [the statement by Samarasiṃha in the Tãjikaśāstra]: 'Male planets in male signs, and female planets in female signs, are strong. The purpose of [designations] such as bilious, hot and cold is to discover the location of an illness from the sixth house, as in [the statement in Varșatantra 10.15]: In the sign where the [planet] causing the illness is [located]', and so on. The purpose of the directions of the signs is to discover the direction of a journey. The purpose of [designations] such as movable signs should be understood to relate to the consideration of meals, as in [the statement] 'When a movable [sign] rises, one eats once. ${ }^{29}$ The purpose of [designations of] the signs as living in water and so forth should be understood to relate to hunting, as in [the statement of Varșatantra 18.34] 'From the planets and signs called watery being strong, they declare a water hunt'. The purpose of [designations of] the signs such as fiery should be understood to relate to such cases as there being danger from fire when a fiery sign is in the eighth house. The purpose of [designations] such as Brahman and other castes, or as fierce and gentle and so forth, should be understood [as in] the statement by Samarasiṃha [in the Täjikaśāstra]: 'Age, dimension and castes ${ }^{30}$ should be known by means of conjecture from the ascendant'. For example, in judging [the question] 'How will I gain this year?', gain of substance of the same colours

27 Literally, 'root-triangle'. This specifically Indian dignity system is similar to but not identical with the Hellenistic signs of planetary 'joys'; see Gansten 2018.

28 Namely, in the order of the days of the week, as usual in Indian sources: the sun, the moon, Mars, Mercury, Jupiter, Venus, Saturn.

29 Source unknown. Other Tājika works differ, stating that a movable sign rising indicates three or 'many' meals. Or, more generally, 'birth [rank], lineage' ( jāti). 
saumyādiprakṛtisahitena tatsamasaṃtānena tatsamabahujalpakenālpajalpakena tatsamavarṇādikavastulābho vācyaḥ | iti rāśisvarūpaprayojanam ||

atha grahasvarūpam | uktaṃ ca yādavena |

ravividhū kșitijo budhavākpatī

bhrguśanī ca tamahśikhinau grahāh |

nava sadā bhramaṇād bhagaṇe nṛnām

dadati dhätusamaṃ phalam uktavat || iti |

vāmano 'pi |

ravyādayo grahāḥ sapta sadasatphaladāyakāh |

munthāphalaviśeșasya jñānārthaṃ rāhur așțamạ̣ || iti |

grahasvarūpam uktaṃ trailokyaprakāśe |

bhārgavendū jalacaraujñajīau grāmacārinau | rāhukșitijamandārkān bruvate 'ranyacārinah \| prabhātam indujagurū madhyāhnam ravibhūmijau| aparāhṇam bhārgavendū saṃdhyā mandabhujaṃgamau \| pittạ̣ prabhākarakșmājau śleșmā bhārgavaśítagū| jñagurū samadhātū ca pavanau rāhumandagau \| kujārkau kațukau jīvo madhuras tubaro budhaḥ| kṣārāmlau candrabhrgujau tīkṣnau sarpārkanandanau \|

\footnotetext{
1 tatsama ${ }^{1}$ matsama $\mathrm{M} \|$ jalpakenālpa] om. K T M $\quad{ }^{1-2}$ jalpakena] janmakena $\mathrm{M} \quad 5$ śikhinau] śikhino B N G K T 6 nava] na ca K T M 19 sarpārka] scripsi; sūryārka B N G K T M

4-7 ravi ... uktavat] TYS 2.38 12-19 bhārgavendū ... nandanau] TLP 19-23
} 
and so on should be predicted through [a person] of the same estate as [the sign in] the eleventh house [or] the ascendant, one endowed with the same fierce or gentle nature and so on, with the same [number of] offspring, who talks correspondingly much or little. This concludes the purpose of [knowing] natures of the zodiacal signs.

\subsection{The Planets}

Next, the nature of the planets; and Yādava says [in Täjikayogasudhānidhi 2.38]:

The nine planets - the sun and moon, Mars, Mercury and Jupiter, Venus and Saturn, Rāhu and Ketu - by their constant orbits through the zodiac yield results for men as declared according to their [respective] elements.

And Vāmana [says]:

The seven planets beginning with the sun are the givers of good and evil results. For the purpose of knowing the particular results of the munthahā, Rāhu is the eighth [planet].

The natures of the planets are stated in Trailokyaprakāśa [19-23]:

Venus and the moon live in water; Mercury and Jupiter live in the village; Rāhu, Mars, Saturn and the sun, they say, live in the forest.

Mercury and Jupiter are morning; the sun and Mars, midday; Venus and the moon, afternoon; Saturn and Rāhu, twilight.

The sun and Mars are bile; Venus and the moon are phlegm; Mercury and Jupiter are of equal humours; Rāhu and Saturn are wind.

Mars and the sun are bitter, Jupiter sweet, Mercury astringent; the moon and Venus salty and sour, [respectively]; Rāhu and Saturn, hot. 
tubaraḥ kașāyah |

sthūla induḥ sitaḥ khaṇdaś caturasrau kujoṣnagū | vartulau saumyadhișaṇau dìrghau śanibhujaṃgamau ||

khaṇḍo 'rdhacandrākāraḥ |

viprau śukragurū kṣatraṃ kujārkau śūdra indujạ̣|

indur vaiśyah smrtau mlecchau saiṃhikeyaśanaiścarau \|

raktavarṇah kujah prokto dhișaṇaḥ kanakadyutị̣|

śukapicchasamah saumyo gaurakāntir anuṣnaguh \|

mandārārkasya pușpena samadyutir athoṣnaguh |

kavir atyantadhavalaḥ phaṇi krșṇah śanis tathā $\|$

avanisso dinamaṇis tapasvī rohinīpriyah |

svarṇakārah kșiteh putro brāhmaṇo rohiṇibhavah \|

vanig guruh kavir vaiśyo vrșalah sūryanandanaḥ|

saiṃhikeyo nișādaś ca sarvakāryeșu sammatah $\|$

yuvā kujah śiśuh saumyah śaśiśukrau ca madhyamau|

mārtandamandadevejyaphaṇinaḥ sthavirā grahāh $\|$

jōvamañgalamārtaṇ̣̂ān uśanti purușān budhāḥ|

somasomajamandāhibhṛuputrā hi yoșitaḥ \|

śukre candre bhaved raupyam budhe svarnam udāhrtam |

gurau ratnayutam hema sūrye mauktikam ucyate |

bhaume trapuh śanau lohaṃ rāhāv asthīni kïrtayet ||

grahāṇāṃ krūrasaumyatvam uktaṃ vāmanena |

jōvendusaumyaśukrāḥ syuḥ saumyāḥ krūragrahāḥ pare|

kṣinnenduḥ krūrayukto jño rāhuḥ krürāḥ prakīrtitāh $\|$

tvañmāmsaromṇām mando 'tha majjāsthnām bhāskarah prabhuh |

kujo raktasya śukrasya bhārgavo medasah śaśī $\mid$

ravih śukro dharāsūnuḥ svarbhānuḥ sūryanandanaḥ|

candro budhạ suraguruh prāgādidigadhīśvarāḥ \|

1 tubaraḥ kașāyaḥ] om. K T M 5 kṣatraṃ] dātrī K; kṣatrī T; kṣattrī M 26 śukrasya] om. K 28 digadhīśvarāḥ] digdhīśvarāḥ B N a.c. G a.c.

2-3 sthūla ... bhujaṃamau] TLP $28 \quad 5^{-21}$ viprau ... kīrtayet] TLP 26-33

1 tubarah kașāyah] K displays a hiatus wide enough for the omitted phrase and marked with something resembling an asterisk. 
'Astringent' [means] sharp. [Continuing from Trailokyaprakāśa 28:]

The moon is large; Venus, split; Mars and the sun, square; Mercury and Jupiter, round; Saturn and Rāhu, tall.

'Split' [means] having the shape of a half-moon. [Continuing from Trailokyaprakāśa 26-33:]

Venus and Jupiter are Brahmans; Mars and the sun, nobles; Mercury, a menial; the moon, a commoner; Rāhu and Saturn are called foreigners.

Mars is said to be the colour of blood; ${ }^{31}$ Jupiter has a golden hue; Mercury resembles [the green of] a parrot tail; the moon has a whitish lustre, and the sun's hue resembles that of a flower of the coral tree; Venus is a dazzling white; Rāhu is black, and so is Saturn.

In all affairs, the sun is considered a king; the moon, an ascetic; Mars, a goldsmith; Mercury, a Brahman; Jupiter, a merchant; Venus, a commoner; Saturn, a menial; and Rāhu, a savage. ${ }^{32}$

Mars is a youth; Mercury, a child; the moon and Venus, middling; the sun, Saturn, Jupiter and Rāhu are old planets.

The learned consider Jupiter, Mars and the sun to be male; the moon, Mercury, Saturn, Rāhu and Venus, indeed, are female.

Silver belongs to Venus and the moon; gold is assigned to Mercury; gold inlaid with gems, to Jupiter; pearl is given to the sun; tin, to Mars; iron, to Saturn; and one should assign bones to Rāhu.

The malefic or benefic nature of the planets is stated by Vāmana:

Jupiter, the moon, Mercury and Venus are benefics; the others are malefics. The waning moon, Mercury [when] joined to malefics, and Rāhu are said to be malefic.

Saturn is ruler of skin, flesh and hair; the sun, of marrow and bones; Mars, of blood; Venus, of semen; the moon, of fat.

The sun, Venus, Mars, Rāhu, Saturn, the moon, Mercury and Jupiter are the [respective] rulers of the [eight] directions beginning with the east. ${ }^{33}$

$31 \quad$ Or simply 'red in colour'.

$3^{2}$ Although these verses partly contradict the ones closely preceding, no attempt at explanation or harmonization is made.

Going from east to south-east, south, etc. 
sūryendujīiāh sattvākhyā jñaśukrau ca rajoguṇau|

svarbhānubhaumaravijās tamogunamayāḥ smṛtāh $\|$

vinașțādigrahalakṣaṇam āha caṇḍeśvaraḥ |

krūradrșto yuto vāpi krūrākrānto viraśmikah |

sa vinașțo bhavet khețo vistaro 'tra nirüpyate \|

rāhuñākrāntadehau tau divākaraniśākarau|

jitaḥ krūrena yạ̣ khețaḥ samarāsisthito 'pi vā $\|$

pāpākrāntah sa nirdiștặ samāmése krūrasamyutaḥ|

antarālavihīno yo drștyā paśyati pürnayā $\|$

sa jñeyah pāpasaṃdrșto raśmihino 'rkamadhyagaḥ|

atha grahasvarūpaprayojanam | tatra brāhmaṇādijātijñānaṃ vựdhhatvādivayojñānaṃ grāmādinivāsajñānaṃ vātādiprakṛtijñānaṃ caturasrādyākṛtijñānaṃ pumān strī ceti jñānam | prayojanaṃ mama kāryam asmin varṣe kena bhavișyatīti praśne varșeśasamajātyādikena varșalagneśasamajātyādikena ca manuṣyeṇa vā kāryam jñeyam | kațukādirasajñānaṃ turyasthakhețavaśato bhojyānne rasam ādiśet ityādyartham | svarnāāidravyoktir varșe sabalagrahasya dravyalābho nirbalagrahasya dravyahānir ityādyartham | prabhātādikāloktir bhojanavicāre kālajñānārtham | grahavarṇaprayojanam varșe sabalagrahavarṇavastulābho nirbalagrahavarṇavastuhānir etajjñānārtham | evam anyad api jñeyam | iti grahasvarūpam ||

6 karaniśā] om. B N G a.c. 8 sa nirdișțah] śanir dișțaḥ B; sa nirdṛsțah G \| samāṃśe] samāṃse B N G 14 varșeśa] varșalagneśa $K$ T M $\|$ varșalagneśa] varșeśa $K$ T M 15 ca] vā K T M || kāryaṃ] kārye B N G 16 vaśato] vasati K T; vasatir M \| artham] uktaṃ K T M 16-17 dravyoktir] divyoktir B N G 18 kāloktir] scripsi; kālokti B N G; kālokter K T M

16 turya ... ādiśet] VT 18.40 
The sun, moon and Jupiter are said to be [of the quality of] clarity; Mercury and Venus have the quality of passion; Rāhu, Mars and Saturn are said to have the quality of darkness.

Caṇ̣eśvara gives the definition of a planet being corrupt and so forth:

A planet that is aspected by or conjunct a malefic, overcome by a malefic or without rays is corrupt. This is detailed as follows: the sun and the moon, when their bodies are overcome by Rāhu, or a planet vanquished by a malefic or occupying the same sign, is declared to be overcome by a malefic; in the same degree, it is conjunct a malefic. One who, with no interval, aspects with a full aspect is known as aspected by a malefic. One located within the sun is without rays.

Next, the purpose of [knowing] the natures of the planets, comprising the knowledge of the castes such as Brahmans; the knowledge of times of life such as old age; the knowledge of abodes such as a village; the knowledge of the humours such as wind; the knowledge of shapes such as square; and the knowledge of male and female [gender]. The purpose [is this]: in [considering] a question such as 'How will my affairs be accomplished this year?', the affairs should be known [to be accomplished] through a person of the same caste and so forth as the ruler of the year, or of the same caste and so forth as the ruler of the ascendant of the year. The purpose of the knowledge of tastes such as bitter is [according to] the statement [in Varșatantra 18.40]: 'One should predict the taste of the food in a meal in accordance with a planet occupying the fourth [house]' and so forth. The purpose of the statement about substances such as gold is that there will be gain of the substance of a planet that is strong in the year and loss of the substance of a planet that is weak, and so forth. The purpose of the statement about times such as morning is knowledge of the time in a judgement about meals. The purpose of [the statements about] the colours of the planets is knowing the gain of objects the colour of a planet that is strong in the year and loss of objects the colour of a planet that is weak. Other [designations] should be understood in the same way. This concludes the natures of the planets. 
atha varṣapraveśavelānayanam | tatsādhanam uktaṃ yādavena |

śako vartamāno januhśákahīno gatābdā bhaveyuś caturdhā nidheyāḥ | bhuvā vānacandrair ilärāmatulyair nabhahpā̄vakais tāạitās te vidheyāḥ $\|$ janmavāraghațikāpalayuktāh șaștyuparyuparigaṃ divasādyam | saptaśeșakam idaṃ dinapūrvā svāgatā bhavati hāyanavelā $\|$

atraiva sugamopāya ukto daivajñacakracūḍāmaṇibhir asmadgurujyeșthabhrātṛbhiḥ śrīmannīlakaṇṭhadaivajñaih |

gatāḥ samāḥ pādayutāḥ prakrtighnasamāgaṇāt|

khavedāptaghațīyuktā janmavārādisaṃyutāḥ |

abdapraveśe vārādi saptatașțe 'tra nirdiśet \|

prakārāntaram uktaṃ grahajñābharaṇe |

iștah śako janmaśakena hīnas tridhā sapādo dalitaś ca sārdhaḥ | yuktas tathā janmagavārapūrvaiḥ sphuțā bhaved abdaniveśavelā || iti |

3 bhuvā vāṇa] bhūvāṇa B N G a.c.; bhūva vāṇa $\mathrm{G}$ p.c.; bhuvā ra vāṇa K || nabhaḥpāvakais] nabhabhapāvakais G a.c.; ilāpāvakais G p.c. T; nabhoṣāvakais K $\quad 4$-ādyam] -āḍhyam M 12 ișțah śako] ișțakośe N

2-5 śako ... velā] TYS 1.9-10 8-10 gatāḥ ... nirdiśet] ST 1.16; VT 1.3-4

3 bhuvā vāna] The $r a$ inserted in $\mathrm{K}$ is almost certainly a wrong reading for an explicatory numeral 1. 13 janmagavārapūrvaih] At the bottom of the page ending in the middle of this word, G gives the following śloka half-verse in a different hand: punar munighnayātābdatriśatyāptapalānvitah. It is not clear where in the text the half-verse is meant to be inserted, nor what its source may be.

34 Or 'welcome' (svāgatā) - a pun on the metre of this verse, likewise called svāgatā.

35 The mathematical operations described here are based on two observations. The first is the length of the sidereal year being 365 days 15 ghațis 31 palas 30 vipalas, each successive unit comprising $1 / 60$ of the preceding. In decimal notation, this corresponds to 365.25875 days, which is within $3^{1 / 2}$ minutes of clock time of the modern average value and within approximately $1 / 2$ minute of the value given in the so-called Liber Aristotilis as the basis of annual revolutions (cf. Burnett and Pingree 1997: 196f.; for the authorship of the Liber Aristotilis, see also Dykes 2019a: 27-32). The second observation is that a 365 -day year in combination with a seven-day week will cause a given calendar date (or, in this case, the position of the sun in a given degree of the zodiac) to advance by 


\subsection{Calculating the Time of the Annual Revolution}

Next, calculating the time of the revolution of the year. How to accomplish this is stated by Yādava [in Tãjikayogasudhānidhi 1.9-10]:

The current Śaka year minus the Śaka year of birth yields the elapsed years, to be kept [separately] in four ways. They should be multiplied by one, fifteen, thirty-one and thirty, [respectively]. Added to the day, ghați and pala of birth [they yield the number of] days and so on [by] repeatedly exceeding sixty. What remains of this after [division by] seven is the well-derived ${ }^{34}$ moment of [the revolution of] the year in days and so forth. ${ }^{35}$

An easy method for the same is explained by the crown jewel in the circle of astrologers, our teacher's elder brother, the illustrious Nīlakaṇṭha Daivajña [in Samjñ̃ätantra 1.16 and Varșatantra 1.3-4]:

One should say that the elapsed years with a quarter added, together with the ghațis [derived by] multiplying the number of years by twenty-one and dividing by forty, and added to the days and so forth of the nativity, are the days and so forth at the revolution of the year, when reduced by multiples of seven. ${ }^{36}$

Another method is explained in the Grahajñābharana:

The year of the era sought minus the year of birth, [treated] in three ways: with a quarter added, halved, and with half added, and likewise added to the days and so forth of the nativity, is the true moment of the revolution of the year. ${ }^{37}$

one day of the week every year. The years elapsed from birth are thus multiplied separately by $1,15,31$ and 30 , the resulting figures converted to greater units where possible, and multiples of 7 subtracted from the final number of days. The remainder in whole days indicates the day of the week sought after, counted from that of birth, while the fractions of a day indicate the number of ghațis, etc., to be added to those of birth in order to find the exact time of the revolution.

36 In other words, for each elapsed year, add $1^{1 / 1} / 4$ days or 1 day 15 ghațis, plus $21 / 40=0.5^{25}$ ghațis or 31 palas 30 vipalas, to the date and time of birth, and reduce the total by multiples of 7 .

37 In other words, for each elapsed year, add $1^{1 / 4}$ days, $1 / 2$ ghați and $1^{1 / 2}$ pala to the date and time of birth. 
evaṃ varșadhruvakavaśāt tājikakartṛbhir aneke prakārā abhihitāḥ | te prayojanābhāvād granthabāhulyabhayāc ca na likhyante ||

atra rātrijanmanīștakālayoge viśeșa uktas tājikālaṃkāre |

niśi janma bhaved yadā tadā gatavārādikam atra saṃyutam | dinamānayutakșapāghațīpalapūrvair iha vāsaro gataḥ || iti |

yad vā rātrijanmani varṣasaṃghotthaghațị̣u rātrigataghațikā yojyāḥ | tatra varșalagnaspașțîkaraṇam saṣaḍbhasūryāt kartavyam yato gataghațikāḥ sūryāstād yātā iti | athavā varșasaṃghotthaghatyādyam iștakālaṃ prakalpya svajanmalagnam raviṃ prakalpya yal lagnaṃ tad varṣapraveśalagnam bhavati | evaṃ sakalagaṇakasārvabhaumaśrīmadrāmadaivajñāptavidyair mādṛ10 śair aneke viśeșāḥ kartuṃ śakyante | paraṃ tu vistarabhayād anudyogaḥ || atredaṃ dhyeyaṃ | yadi caitrāder anantaram api mīnārke janma tadā pūrvavarșaśaka eva janmaśakaḥ kalpyaḥ | evaṃ janmārkasamabhānuś caitrāder ūrdhvaṃ meșādeḥ prāg bhavati tadā prāgabdaśaka evābhịștaśakaḥ kalpyah | meșāder ūrdhvaṃ tv agrimaśaka eva jñeyaḥ | anyathādhimāsasambhave kadācid ekacāndravarṣamadhye dvivāraṃ janmārkasamabhānoḥ sambhavena varșadvayotthavārādivailakṣaṇyam apekṣitam api gatasamāsāmyān na syāt | evam adhimāsasahitavarșād agrimavarșe kadācic cāndravarșam ullañ-

1 abhihitāh] bhihitās B N G K T $\quad 3$ atra] athātra K T M $\quad 7$ sașaḍbha] saṣațka M 9 sva] sa K T M 13 kalpyah] prakalpyah K T M 14 kalpyah] prakalpyah K T M 15 sambhave] sambhavam B N G 16 eka] eva K T M 
Thus numerous methods have been devised by Tãjika authors on the basis of the constant of the year; but they are not written [here] because it would serve no purpose, and from fear that it would swell the book.

Now, a special rule for deriving the time sought in a nocturnal nativity is stated in the Täjikälaṃkāra:

When the birth was at night, then the elapsed days and so forth added to the length of the day in addition to the ghațis, palas and so forth of night [make up] the elapsed day here.

Or, in a nocturnal nativity, the elapsed ghațis of night may be added to the ghațis produced by the accumulated years, and then the true ascendant of the year calculated by adding six signs to [the position of] the sun, because the elapsed ghațis are taken from sunset. Or else, putting the ghațis and so forth produced by the accumulated years in the place of the time sought, and putting the sun in the place of one's ascendant in the nativity, the ascendant [calculated for that time] is the ascendant for the revolution of the year. Thus, persons such as myself, who have received their knowledge from the illustrious Rāma Daivajña, sovereign of all mathematicians, can devise numerous particular methods; however, for fear of prolixity, I do not undertake [to do so].

Here the following should be considered: ${ }^{38}$ if birth was after the beginning of [the lunisolar month] Caitra, but with the sun in Pisces, then the previous Śaka year should be taken as the Śaka year of birth. Likewise, if the return of the sun to its natal position takes place after the beginning of Caitra but before the beginning of [the solar month of] Aries, then the previous Saka year should be taken as the Śaka year sought; but after the beginning of Aries, it should be known to be the next Śaka year. Otherwise, because the sun may sometimes return to its natal position twice within a single lunisolar year when there is an intercalary month, there will not be the expected difference in days and so forth between two years, due to the dissimilarity between the elapsed years. Likewise, in the year following a year contain-

38 This paragraph addresses the difference between the true (sidereal) solar year and the Indian lunisolar year consisting of 12 synodic months beginning with Caitra, when the full moon falls in or near the asterism Citrā. The sun will then be in late sidereal Pisces or early sidereal Aries. The typical lunisolar year lasts approximately 354 days and is thus shorter than a solar year; but when the discrepancy between the two becomes too great, it is adjusted by intercalation, making the lunisolar year longer than a solar year. 
ghyāpi janmārkasamabhānau jāte saty ekavarṣavārādisamaṃ vārāder antaraṃ ca syāt | tasmāt sauravarșādau śakapravṛttir jñeyeti | atra janmārkatulyo ravir yasmin māse bhavati tasminn eva māse varșapraveśo jñeyah | uktaṃ ca

tatra janmārkasamo ravir yadi janmamāse nāyāti pare pūrve vā māse āyāti tadā janmamāsa ekarahita ekayukto vā kartavya iti ||

atha varṣadhruvakopapattị̣ | atra varṣādiḥ sādhyas tac ca sauram eva | uktaṃ ca siddhāntaśiromaṇau |

varșāyanartuyugapūrvakam atra saurāt $\mid$ iti |

atha raveś cakrabhogo 'rkavarșaṃ pradiștam iti tatraivoktatvād ravibhagaṇabhogena sauravarṣam bhavati | tatra spașțagateś cañcalatvāt sauravarṣādiḥ kadā bhaviṣyatīti jijñāsāyāṃ pratyakṣopalabdhyā janmakālīnasūryatulyạ sūryo yasmin dine tatra bhagaṇabhogasya jātatvād varṣādir jātạ̣ | tasya jñāne upāyah | yadi kalpasauravarșaiḥ kalpasāvanadināni labhyante tadai15 kena kim iti prāptā ekasmin varșe ete sāvanāhāḥ 365|15|31|30 | vārasyaivāpekṣitatvād upari saptatașțāh jātāḥ 1|15|31|30 | atrānupātạ̣ | yady ekasmin varșe ete sāvanāhās tadā bhuktāyurvarșaị kim iti | anena gatavarșāṇi caturdhā gunyyāni rūpeṇa bhājyāni | phalaṃ janmasamayād ārabhya

8 sauram eva] sauravema B G; sauraveme N 11 tatrai-] tenai- K T M 12 bhogena] bhogyena B N G \| sauravarșaṃ] saure varșo K T $\|$ tatra] tasya K T M 14 bhogasya] bhogyasya B N G 15 labhyante] om. B N G 16 prāptā] prāptau M \| ekasmin] evāsmin B p.c. \| ete] om. B N G || 30] 31 B N || vārasyaivā-] vārasyaiva- G; vārasyaikya- K T; vārasyaikyā- M 17 30] 31 B N G p.c. 18-19 anena ... caturdhā] atra gatavarșāṇi anena dhruvakena o1 $|15| 3^{1} \mid 3^{\circ}$ caturṣu sthāneșu K T; atra gatavarșāṇi anena dhruvakeṇa o1|15|31|30 caturṣu sthāneșu M 19 samayād] samād B N G

5 tithyādi ... māsah] PBh 7 10 varṣā ... saurāt] SŚ $1.31 \quad 11$ raveś ... pradișțam] SŚ 1.19 
ing an intercalary month, even when the sun passes over a lunisolar year in returning to its natal position, the difference in days and so forth will equal the [difference in] days and so forth of a single year. Therefore, the calendar year should be understood to commence at the beginning of the solar year: [only] then can the revolution of the year be known to take place in the same month in which the sun returns to its natal position. For it is said [in Paddhatibhūṣaṇa 7]:

When, in the table of tithis and so forth, [the longitude of] the sun is equal to [that of] the sun in the nativity, that is the month.

Therefore, when the sun does not attain the same [longitude] as the natal sun in the natal month, [but] does attain it in the following or preceding month, then the natal month should be decreased or increased by one.

Next, the demonstration of the constant of the year. Here the beginning of the year is to be found, and that [year] is only a solar one. For it is said in Siddhāntaśiromaṇi [1.31]:

Here [the units] beginning with a year, a half-year, a season and a yuga $^{39}$ [should be derived] from the solar [measure].

Now, since it is said in the same [work, 1.19]: 'The sun's completion of a revolution defines the solar year', a solar year comes to be by the sun completing a revolution of the zodiac. And because [the sun's] true motion is variable, if one wants to know when the solar year will begin, the year begins on that day when, by empirical observation, [the longitude of] the sun is equal to [that of] the sun at the time of birth, because then it has completed a revolution of the zodiac. The method for [obtaining] knowledge of that [is as follows]: if by such a number of solar years such a number of civil days are obtained, then how much [is obtained] in one [year]? Thus in one year $365 ; 15,31,30$ civil days are obtained. ${ }^{40}$ Because only the day of the week is wanted, the exceeding [figure] is reduced by multiples of seven, giving 1;15,31,30. Then proportion [is applied]: if these are the civil days in one year, then how many [are produced] by the completed years of life? The elapsed years are to be multiplied by this [figure] in four ways and divided by the [respective]

39 In this contex, yuga is probably used in the sense of world age.

40 That is, in sexagesimal notation (cf. note 35 and the Introduction). 
sāvanadināni | asmin janmavārādiyogas tu varșapraveśíyadivasaghațīpalajñānārthaṃ kṛtaḥ | atra palaghațībhyaḥ șașțā ūrdhvordhvayojanaṃ palaghaținnām șaștyadhikatvābhāvāt kṛtaṃ | vārāḥ saptaivātah saptatașțam ity uktam | evaṃ kṛte tasmin sāvayave dine varṣādiḥ sphuṭo bhavatīty upapannam | athaikavarșapraveśād agrimābdādipraveśajñānam |

\section{bhūvānavidhubhūrāmakhāgnivārādikena yuk| varșamāsadinād veśo 'grimah syāt tithir iśayuk || iti |}

nanu sauravat sāvanacāndranākṣatrabārhaspatyavarṣāṇām sambhavāt katham sauramānenaiva varṣapraveśo 'bhihitah \|

tatrocyate | cāndrasāvanavarșayos tu sūryasya candrasya vā sāmyābhāvāt tyāgah | bārhaspatyamāne tu janmakālikarāśyādimadhyamaguruṇā abhīṣtabārhaspatyavarṣe yady api guror aṃśasāmyam bhavati tathāpi rāśisāmyābhāvāt tyāgah | nākșatravarșānte yady api candrasāmyaṃ bhavati tathāpi grahāgresarasya grahāṇām tejodātuś ca raveḥ sauravarṣe rāśyaṃśakalāvikalāsāmyād atha ca varșāyanartuyugapūrvakam atra saurāt iti siddhāntokter yā̄ān janmani bhānuḥ ityādijīrṇatājikokteś ca sauramānenaivābdapraveśakaraṇam yuktam \|

atha ca māsair dvādaśabhir varșam iti sūryasiddhāntokter varșabhāskaralavena samāvat spaștamāsaphalam ādiśet sudhịh iti jīrṇatājikokteś ca sauramānenaiva māsapraveśo 'pi vidheyaḥ ||

1 dināni] dinānīti K T M $\quad 2$ yojanaṃ] -yor janam K T; -yor janma M 7 dinād veśo] dināveśo K T M 8 sauravat] sauravarșāt K T M $\|$ sambhavāt] sambhave K T M 11 māne tu] mānena K T M 12 bhavati tathāpi] tathāpi + bhavati + B $\quad 15$ ca $]$ om. K T M 19 spaṣṭa] sāṣța K M

15 varșā ... saurāt] SŚ $1.31 \quad 18$ māsair ... varșam] SūS 1.13

41 Text witnesses K T M give a more explicit reading: 'Here the elapsed years are to be multiplied by this constant of 1;15,31,30 in four places and divided by the [respective] unit.' In other words, the vipalas are divided by 60 to form palas (with a remainder in vipalas); the palas are divided by 6 o to form ghațiss; and the ghațis are divided by 60 to form days.

42 The source of this quotation is unknown.

43 Näkșatra, that is, a purely lunar year consisting of twelve revolutions of the moon with respect to the fixed stars, grouped into 27 asterisms (nakșatra) standardized as equal ecliptical segments $\left(27 \times 13^{\circ} 20^{\prime}=360^{\circ}\right)$. 
unit. ${ }^{41}$ The result is [the number of] civil days reckoned from the time of the nativity; and this is added to the day of the week and so forth of the nativity in order to know the day, ghațis and palas pertaining to the revolution of the year. Here, palas and ghațis exceeding sixty are converted into a higher [unit] because palas and ghațis cannot exceed sixty. The days of the week are only seven; therefore, reduction by multiples of seven is prescribed. This having been done, the true beginning of the year falls on that day with its fractions. Thus it is proved. From the revolution of one year, knowledge of the revolutions of the following year and so on thus [arises, as it is said]:42

The following revolution [is found] from the [previous] year, month [and] day [by] adding one, fifteen, thirty-one and thirty days and so forth. The lunar date [is found by] adding eleven.

Objection: since it would have been possible [to use] the civil, lunisolar, sidereal $^{43}$ or Jovian year, just like the solar year, why is the revolution of the year set forth using only the solar measure?

[In reply] to that it is said: the lunisolar and civil years are rejected due to the variability of [the motion of] the sun and moon. As for the Jovian measure, although Jupiter may attain the same degree in the Jovian year sought through the mean [motion of] Jupiter beginning from the zodiacal sign [it occupied] at the time of birth, nevertheless it is rejected due to the variability in sign [position]. [And] although [the position of] the moon is the same at the end of a sidereal year, nevertheless, because in a solar year the sun, who is foremost among the planets and giver of light to the [other] planets, attains the same sign, degree, minute and second; and because of the statement of the Siddhanta[siromaṇi 1.31] that 'here, [the units] beginning with a year, a half-year, a season and a yuga [should be derived] from the solar [year]'; and also because of the statement of the ancient Tâjikas [namely, Samarasiṃha, in the Täjikaśāstra], 'As far as the sun [had gone] in the nativity' and so on, it is fitting to make the revolution of the year conform only to the solar measure.

Furthermore, according to the statement of Süryasiddhānta [1.13] that 'the year [consists] of twelve months', and the statement of the ancient Tājikas: ${ }^{44}$ 'The wise should predict the true result of a month from the degree of [longitude occupied by] the sun of the year, just like [the result of] the year [itself]', the revolution of the month should be established only by the solar measure. 
nanu māsās tathā ca tithayas tuhināmśumānāt iti siddhāntokter māsapraveśe cāndramāsasyaiva mukhyatvam iti cen na | yathā sauramāsapraveśe sūryāṃśasāmyaṃ jñāpakaṃ na tathā cāndramāsapraveśe kiṃcid asti | athavā adhikamāsasambhave trayodaśamāsānāṃ sattvāt pūrvoktaṃ sūryasiddhāntavaco lokaprasiddhiś ca vyāhanyeta | tasmāt sauramānenaiva māsadinapraveśādikaṃ vidheyam iti siddhāntah ||

atha varșapraveśasamaye svasvādhītasiddhāntakaraṇādirītyā sādhito'rko janmakālīnārkeṇāvaśyaṃ samo bhavati | idam eva varṣapraveśasamaye pramāṇam | uktạ̣ ca samarasiṃhena |

yāvān janmani bhānus tāvān varșe sphuțas tathaivam api

śrīmannīlakaṇṭhajyotirvidbhir apy uktam |

tatkāle 'rko janmakālaraviṇā syādyataḥ samaḥ| iti |

evaṃ niṣpannasyābdapraveśakālasya spașțīkaraṇam uktaṃ haribhaț̣tena tājikasāre |

sūryo varșasamudbhavo na hi bhavej janmārkatulyo yad̄̄

tadgatyā vihṛtam tayos tu vivaram labdham ca hinānvitam |

varșāveśaghațīpaleșu satataṃ varșārkahinādhike

janmotthe dyumaṇau hi varșasamayas tv evam bhavet prasphuțah || iti |

5 prasiddhiś] prasiddhaś $\mathrm{K}$ T; prasiddhaṃ $\mathrm{M} \quad 6$ siddhāntaḥ] rājñaṃtaḥ B G; ră*ṃtaḥ N 13 niṣpannasyābda] niṣpannasyādvarșa B N p.c. G p.c. 16 vihṛtaṃ] vihitaṃ N G 18 prasphuțah] prasphuțam K T M

1 māsās ... mānāt] SŚ $1.31 \quad 12$ tatkāle ... samah] VT 1.5 $15^{-18}$ sūryo ... prasphuṭah] TS 41 
If it should be objected that, according to the statement of the Siddhänta[śiromañi 1.31], 'Months and lunar dates [should be calculated] by the lunar measure', the lunisolar month alone takes precedence in a monthly revolution, [then we say]: not so, [for] while the commencement of a solar month is marked by the sun attaining the same degree [in another zodiacal sign], there is no such [marker] at the commencement of a lunisolar month. ${ }^{45}$ Moreover, because there will be thirteen months [in a year] when there is an intercalary month, the statement of the Süryasiddhānta quoted above, as well as common usage, would be contradicted. Therefore, the conclusion is that the revolution of the month and day and so forth should be established only by the solar measure.

Now, at the time of the revolution of the year, [the longitude of] the sun, established by whatever method one has studied, whether a [full astronomical] system or an [abridged] manual or so forth, will necessarily be the same as [the longitude of] the sun at the time of birth. This alone is the [true] measure of the time of the revolution of the year. For Samarasimpha says [in the Täjikaśāstra]:

As far as the sun [had gone] in the nativity, that far likewise is [its] true [position] in [the revolution of] the year.

And the illustrious Nīlakaṇțha Jyotirvid ${ }^{46}$ says [in Varșatantra 1.5]:

Because [the longitude of] the sun at that time would be the same as [that of] the sun at the time of birth.

A correction of the time of an annual revolution thus derived is described by Haribhațta in Tājikasāra [41]:

When [the longitude of] the sun derived in [the revolution of] the year is not equal to [that of] the sun in the nativity, the difference between them is removed by its motion, [making] the result smaller or greater. Whenever [the longitude of] the sun in the nativity is smaller or greater than [that of] the sun of the year at the ghațis and palas of the revolution of the year, that will give the true [beginning of the] year.

45 The beginning of a lunisolar or synodic month is marked by the moment of the exact conjunction or opposition of the sun and moon. Balabhadra is implicitly saying that a marker relating to zodiacal position is required.

46 Used here as a synonym of Daivajña. Both bynames mean 'astrologer'. 
pārthapuranivāsigaṇeśadaivajñenāpy uktaṃ tājikabhūṣaṇe |

janmakālanalin̄ivilāsinā naiva yāti tulanām kalāsu cet | varșakālanalinīpatis tayor antaram gatihṛtaṃ yutonitam || kāryaṃ varșadhruve tasmād asau spașțaḥ prajāyate | iti |

atra varṣārkajanmārkasāmyābhāvāt kālasya spașțikaraṇam uktam | tatra svādhītakaranāt svadeśapūrvāparayāmyottarādikarmasaṃskṛto janmakālīnaspașțārkah | tatkaraṇajātadeśāntarādisaṃskṛto vārṣikaspașțārko janmārkasamo 'vaśyam bhavati | tadāsāmyam tu khapuṣpāyamānam | atra dhūlīkarmaṇāpy ajñānam ātmano dūrīkarotv āyuṣmān | etad ganitapūrvakaṃ sakalabhūpālamūrdhāmaṇinīrājitacaraṇakamalānāṃ bhūmaṇḍalākhaṇ̣alānāṃ śrīsāhisujāmahāprabhūṇāṃ māsapraveśānayane likhyate | atah kālaspașṭikaraṇam ayuktam ||

atha yady evam ucyate | pūrvoktānupātasādhitatvāt kalpamadhyamabhagaṇotthaḥ sāvanadhruvo 'pi grahavan madhyamas tatsādhitavarṣakālasyāpi madhyamatvam | madhyamaspașțikaraṇaṃ yuktam eveti | tad api na | yataḥ sauravarșānte samupacayāpacayasāmyena madhyamaspaștasāvanayos tulyatvāt sauravarșāntaḥpātisaptataștasāvanadhruvaḥ spașța eva | tatsādhito 'bdādiḥ sutarāṃ spașta eva | spașțasya punạ̣ spașțikṛtir na yujyate | ata eva yāoān janmani bhānuḥ iti padyena tājikakartṛșu ṛ̣isthānā-

2 tulanāṃ] tulatān K T M 5 janmārka] janmārkasya B N G \|| kālasya] kāla KT M 6 svādhīta] svādhīnat B N p.c.; svādhītat G 12 likhyate] likhisye B; likhisthe N G 14 sāvana] sāyana K T M || dhruvo] dhruve M 16 samupacayāpacaya] samupacayāya B N G || madhyama] madhya B N G; madhyamadhyama T M $\quad$ 16-17 sāvanayos] sāyanayos K T M $\quad 17$ sāvana] sāyana K M 18 kṛtir] karaṇan K T; karaṇaṃ M

2-4 janma ... prajāyate] TBh $1.8-9$

47 That is, something non-existent or impossible.

48 Literally, 'dust-work' (dhülïkarman), referring to the practice of writing calculations on a board covered with dust.

49 See section 8.3.

$5^{\circ}$ As on many matters of controversy on which he pronounces, Balabhadra is wrong and the authors he criticizes are right: the duration between two observable returns of the sun to the same point of sidereal longitude may in fact vary by up to 25 minutes or so of clock time. This is chiefly due to the phenomenon of perturbation, caused by the gravitational attraction of other bodies on the 'Keplerian orbit' of the earth and not generally understood before Newton. I am indebted to James Evans for this explanation. With what precision Haribhața or Ganeśa Daivajña were able to determine the sun's longitude either by observation or by calculation is a more difficult question to answer. At least part of the discrepancy they noted would presumably have been 
And Gaṇeśa Daivajña of Pārthapura says in Tājikabhūṣaṇa [1.8-9]:

If the sun at the time [of the revolution] of the year does not equal the sun at the time of birth in its minutes of arc, the difference between them divided by the [sun's daily] motion should be added or subtracted to the constant of the year; by that [procedure] the true [time of the revolution] is derived.

Here, correction of the time is prescribed when [the longitudes of] the sun in [the revolution of] the year and the sun in the nativity do not agree. Concerning that [we say]: the true [position of the] sun at the time of the nativity is [taken] from the manual one has studied and corrected for one's own place by the east-west and north-south procedures and so forth; [and] the true [position of the] sun in the annual [revolution], rectified for difference of place and so forth by [the procedures] given in that [same] manual, will necessarily be the same as [that of] the sun in the nativity. The disagreement [between the two] is then transformed into a flower in the sky! ${ }^{47}$ Let the honourable [reader] dispel his ignorance on this matter by calculation. ${ }^{48}$ This [procedure] is written, accompanied by figures, in the calculation of the monthly revolution of his majesty Śrī Shāh Shujā', the vanquisher of the sphere of the earth whose lotus feet are illuminated by the crown jewels of all its kings. ${ }^{49}$ Therefore, a correction of time is improper. ${ }^{50}$

Now, if it should be said thus: that because it is established by proportion as described above, the constant of the civil [solar year], produced by mean revolutions of the zodiac in a period just as [is done for] a planet, is a mean [value]; that the duration of the year established by it is likewise a mean one; and that it is proper to correct a mean [value] - even then [we say] no, because at the completion of a solar year, the mean and true civil [solar years] are identical, the increases and decreases [in the sun's motion] being equal; ${ }^{51}$ hence the constant of the civil [solar year] that, reduced by multiples of seven, is implicit in the solar year, is indeed a true [value], and the beginning of the year established from it is most definitely true. And [to attempt] to correct a true value further is not proper. Therefore, with the verse beginning 'As far as the sun [had gone] in the nativity', Samarasimpha,

caused by the slight misestimation of the length of the sidereal year used by Täjika authors. For the error margin of Balabhadra's calculations, cf. Chapter 8, note 26.

$5^{1}$ The daily apparent motion of the sun varies slightly according to season, but the total increase and decrease from its mean value will balance each other out over the course of a year. 
bhiṣiktena samarasiṃhena varṣakālaspașțîkṛtim vinaiva spaștāarkasāmyam uktaṃ na tu madhyamārkasāmyam | ato haribhaț̣agaṇeśadaivajñakṛtaṃ kālaspașțîaraṇam ayuktam ||

idaṃ punar ihāvadheyam | prativarșam ekā kalāyanāṃśagatir iti janmano bhūyasi kāle gate 'yanāṃśavaśenodayāntaracarāntarayor vailakṣaṇyāt tatsaṃskṛtas tatkaraṇajataddeśāntarādisaṃskṛto 'pi varṣārko janmārkasamo na bhavati | tadartham anupātenāntaram sādhyam | tad yathā | yadi sūryaspașțagatikalābhị̣ șaștighațikās tadārkāntarakalābhị̣ kim iti | labdhanāḍyādyena varṣāveśakālạ̣ saṃskārya iti | tasmāt tatkaraṇajataddeśāntarabhujāntarasaṃskṛto 'bhịștāyanāmśavaśād utpannodayāntareṇa taddeśajapalabhotthatātkālikacareṇa ca saṃskṛto varṣārko janmārkasamo yadi syāt tadaiva kālasya spașțatvam anyathā neti siddhāntah | śrīmannīlakaṇṭhadaivajñais tu svalpāntaratvān noktam ato na ko 'pi doṣah || atha varṣapraveśe tithyānayanam uktam paddhatibhūṣaṇe |

samāsamājaḥ śitikaṇthanighnaḥ samāṣțibhāgena samanvito 'sau| svajanmatithyā ca kharāmataștas tithir bhaved bhünayutā kadācit || iti |

nakṣatrayogānayanam apy uktam tājikasāre |

2 ato] ata eva KTM 6 tatkaraṇaja] tatkaraṇātKTM $\|$ tad] tattad KTM 9 nāḍādyena] nājyādyena K; bhājyādyena M \| tatkaraṇaja] tatkaraṇajas G p.c. T 12 yadi] na add. B N a.c. G K T M || kālasya] kāla G K M 15 samājaḥ] samānaḥ N \|| 'sau] syai M 17 apy] om. K $\mathrm{TM}$

15-16 samā ... kadācit] PBh 6

12 yadi syāt] Although all text witnesses include the negation $n a$ in this phrase and only one erases it again, the sense and context require that it be omitted.

$5^{2}$ This value is approximately 10 seconds of arc greater than the modern calculated value, although the rate of precession is not constant but will vary somewhat over large periods of time.

53 Balabhadra's point is that the corrections for the obliquity of the ecliptic and for ascensional difference are based on tropical parameters, and that the tropical longitudes corresponding to a single sidereal longitude will be slightly different in different years owing to the continuous precession of the equinox.

$54 N \bar{a} d \bar{l}$ is a synonym of ghațī, or $1 / 60$ of a nychthemeron.

55 That is, from its terrestrial latitude. Cf. note 24.

$5^{6}$ This sentence sums up the four corrective procedures (samskāra) employed to find the true longitude of a planet: deśāntara, addressing variations in the time of sunrise caused by terrestrial longitude; cara or ascensional difference, addressing variations in the length of the day caused by terrestrial latitude; and the equation of time consisting of bhujāntara and udayāntara, addressing the eccentricity and obliquity of the eclip- 
who is anointed to the rank of a sage among Tajika authors, describes the identity of the true [positions of the] sun, and not [merely] the identity of the mean [positions of the] sun, even without any correction of the duration of the year. Therefore, the correction of time made by Haribhatta and Ganeśa Daivajña is improper.

Here, moreover, the following should be taken into account: the rate of precession is one minute of arc per year. ${ }^{52}$ Hence, when a long time has passed since birth, the disparity in the corrections for obliquity and ascensional difference means that [the longitude of] the sun in [the revolution of] the year, corrected for those factors, will not be the same as [that of] the sun in the nativity, despite being corrected for longitudinal difference for that [same] place given by that [same] manual, on account of precession. ${ }^{53}$ For that sake, the difference must be established by proportion, as follows: if the minutes of arc in the true [daily] motion of the sun give sixty ghatīs, then how much do the minutes of arc in the difference [in the longitude] of the sun give? The time of the revolution of the year should be corrected by the resulting nădīs and so forth. ${ }^{54}$ Therefore, if [the longitude of] the sun in [the revolution of] the year, corrected for eccentricity and for the longitudinal difference of that place as given in that [same] manual, and corrected for obliquity as derived from the precessional value [for the time] sought and for the current ascensional difference derived from the equinoctial shadow of that place, ${ }^{55}$ is the same as [that of] the sun in the nativity, only then is the time correct, [and] not otherwise: this is the conclusion. ${ }^{56}$ But [this] has not been stated by the illustrious Nìlakanțha Daivajña on account of the minuteness of the difference [caused; and] there is no fault in this.

Next, the calculation of the lunar date in the revolution of the year is described in Paddhatibhūṣaṇa [6]:

The accumulated years multiplied by eleven, added to a sixteenth part of the years and to the lunar date of one's birth is the lunar date [of the revolution when] reduced by multiples of thirty, sometimes plus or minus one.

And the calculation of the asterism and yoga is described in Tājikasāra [12]:57

tic, respectively. The last three are often combined and referred to as tryaikya or 'the triad'; cf. section 8.2 below.

57 In this context, yoga refers to one of the five elements of the Hindu almanac or pañcānga, namely, the sum of the sidereal longitudes of the sun and moon, grouped into 27 segments. 
vyomendubhị saṃgunitā gatābdāḥ svaśūnyavedāśvilavair vihīnāḥ | janmarkșayogaị sahitā prthaksthā nakșatrayogau bhavato bhataștau \|

lagnānayanam uktaṃ paddhatau |

samāsamājas trigunạ̣ samānāṃ daśāṃśayukto janilagnayuktaḥ| sūryoddhṛtah śeșasamam vilagnam sāmānyato mānyatamair agādi || iti |

atra tithinakșatrayogā varṣapraveśadivasasya prāyo naikațyenāyānti | uktam ca sudhānidhau ||

niścayo 'tra sadā jñeyo vārāt sarvatra hāyane |

tithībhayogato jñeyam anumānaṃ bhayogayoh || iti |

lagnam api kālanaikațye samāyātīti jñeyam | tatra saṃkrāntijñānārthaṃ 10 daivajñamukuṭālaṃkārāṇāṃ sakalagaṇakasārvabhaumānām asmadgurucaraṇānāṃ śrīrāmajyotirvidāṃ padyāni ||

śāke 'ñkadasreșumahìvihīne tristhe sapāde dalite ca sārdhe | khenāștavedaị krtibhị̣ krameṇa yukte 'dritașțe kriyasaṃkramah syāt ||

athaikasyāṃ meșasaṃkrāntau jñātāyāṃ tadagrimasaṃkrāntijñānārtham 15 sūtram |

dasrau śailaśarā rasā guṇayamās trīni dvayaṃ șad viyadrāmā dvau khaguṇā krtā rasaśarā șaṇ nāgavedāḥ kramāt | bhūmih saptadaśa dvayạ̣ rasaguṇa vedās trayạ̣ mārgaṇās tryakșā vāsaranādikās tv ajadinād ye yojitāḥ syur vrṣāt ||

1 sva] kha M. 14 khenāṣța] șenāṃșa B N; șenāṃșța G || 'dri] dvi M 15 athaikasyāṃ] athaikasmin K T M

1-2 vyomendubhị ... bhatașțau] TS $12 \quad$ 4-5 samā ... agādi] PBh $8 \quad$ 8-9 niścayo ... yogayoh] TYS 1.26 
The elapsed years multiplied by ten, less by a two hundred and fortieth part of themselves, and added separately to the asterism and yoga in the nativity, are the asterism and yoga [of the revolution, when] reduced by multiples of twenty-seven.

The calculation of the ascendant is described in Paddhati[bhüșaṇa 8]:

[When] the accumulated years multiplied by three, added to a tenth part of the years and to the ascendant of birth, is divided by twelve, the ascendant is said by the worthy generally to equal the remainder.

Regarding this, the lunar date, asterism and yoga generally fall near to [but not necessarily on] the day of the annual revolution. And it is said in [Tājikayoga]sudhānidhi [1.26]:

In every [revolution of the] year [the time] will be known with certainty [only] from the day of the week; from the lunar date, asterism and yoga [only] a conjecture will be known regarding the asterism and yoga [in the revolution].

The ascendant, too, should be understood [merely] to fall near to the [correct] time. In connection with that, [here are some] verses by the crown ornament of astrologers, the sovereign of all mathematicians, our venerable teacher Śrī Rāma Jyotirvid, for knowing [the time of] an ingress:

When fifteen hundred and twenty-nine is subtracted from the Saka year [and the result set down] in three places, with a quarter added, halved, and with half added, and added to nil, forty-eight, and twenty, [respectively, and then] reduced by multiples of seven, that is [the day of] the Aries ingress.

Next, when [the time of] one Aries ingress is known, a mnemonic verse for knowing [the times of] the following ingresses:

Two and fifty-seven, six and twenty-three, three and two, six and thirty, two and thirty, four and fifty-six, six and forty-eight, one and seventeen, two and thirty-six, four and three, and five and fifty-three, [respectively], are the days of the week and the nädis which are to be added to the day [and time] of the Aries [ingress, beginning] from Taurus. 
atha saṃkrāntitithijñānopāyaḥ|

śāke navāśvitithyūne rudrai rāmair guṇeșubhị̣|

nighne rudrānvite khāgnitaște meșāhajā tithị \||

dvivedāngāștadigrudrayutā syād anyasaṃkrame |

dvidvidvidvidvibhūbhirvā yuktā buddhyā kramāt parā || iti |

\section{meșasaṃkrānti- tithyādikṣepakāḥ vārādau kṣepakāḥ}

\begin{tabular}{lll}
\hline meșaḥ & o o & 0 \\
vṛ̦abhạ̣ & 257 & 2 \\
mithunạ̣ & 623 & 4 \\
karkațạ̣ & 32 & 6 \\
siṃhạ̣ & 630 & 8 \\
kanyā & 230 & 10 \\
tulā & 456 & 11 \\
vṛ́cikạ̣ & 648 & 11 \\
dhanụ̣ & 117 & 11 \\
makaraḥ & 236 & 11 \\
kumbhaḥ & 43 & 11 \\
minnạ̣ & 553 & 11 \\
\hline
\end{tabular}

3 nighne] nighno K || rudrānvite] rudrānvito K || taștẹe] tașțo K || meșāhajā] meșāhajās K 4 rudra] rudrā G K 5 dvidvidvidvidvi] dvi2dvi2dviradvi2 K T \| bhūbhir] scripsi; mi B G N a.c.; bhūmir N p.c. K T M 12 8] o K T M 14 56] 26 B 16 17] 20 K; 27 T 19 53] 23 M

5 dvidvidvidvidvi] The reading -dvira- of $\mathrm{K} \mathrm{T}$ is almost certainly the result of an explicatory numeral 2 being misread as $r a$. $\|$ iti] At this point $G$ inserts the following rather corrupt stanzas: || atha tripatākiphalam || vedhayet ekareșāyā rāhucaṃdranarasya ca || tadā kașta vijānōyāt tatvararveśunișitam || rāho caṃdrasya vedhe tu || tathaiva śanibhaumayo || tatra varșe bhavet mrtyurogātigamane raṇe $\|2\|$ rāho jīvasya vedhe tu $\|$ mrtyur eva na samśayah subhavedhe bhavet saukșaṃ lābho bhavati niścitạ̣ $\|3\|$ krūras tanugate marmạ̣ kaṃțakaś ca trikoṇagai || śalyaṃșakrūryagai krūrai || chidraṃ trirudragai svapnai $|4| \mid$ marmavedhe bhave mrtyu kaṃțake ca kulakṣayam || śalyai nṛpatito bhiti tasmāta jñeyaṃ vicakṣaṇai 5 || iti tripatākācakraphalam \| 6 meșa] The following table is omitted by N. K T M add the heading rāśi (rāsí $\mathrm{M}$ ) for the first column and give the headings for the second and third column as vāra ghațī (ghațikā $\mathrm{M}$ ) and tithi (ti K T), respectively. 
Then, a method for knowing the lunar date of an ingress:

When fifteen hundred and twenty-nine is subtracted from the Śaka year [and the result] multiplied by eleven, three, and fifty-three, with eleven added and reduced by multiples of thirty, [the end result] is the lunar date of the day of the Aries [ingress]. For an ingress into another [sign], two, four, six, eight, ten and eleven is added; then two, two, two, two and two ones are added intelligently, in order.

Additive values for the Additive values in

Aries ingress in days of lunar dates, etc.

the week, etc.

\begin{tabular}{lll}
\hline Aries & o o & 0 \\
Taurus & 257 & 2 \\
Gemini & 623 & 4 \\
Cancer & 32 & 6 \\
Leo & 630 & 8 \\
Virgo & 230 & 10 \\
Libra & 456 & 11 \\
Scorpio & 648 & 11 \\
Sagittarius & 117 & 11 \\
Capricorn & 236 & 11 \\
Aquarius & 43 & 11 \\
Pisces & 553 & 11 \\
\hline
\end{tabular}


atha varṣapraveśe saṃkṣiptapañcāngaphalam uktaṃ trailokyaprakāśe |

nandābhadrājayāpūrṇāh śubhadās tithayo matāḥ|

dvādaśy ādyā ca riktāś ca na śubhā varșaveśane \|

somo budho guruh śukro vārāś catvāra uttamāh |

bhaumārkaśanivārāś ca varșe hānibhayapradāh \|

aśvinī mrgaśîrșam ca hastah pușyah punarvasuh |

svātiś ca revatī caiva varșaveśe śubhāvahāh \|

krttikā rohin̄i cārdrā jyeșțhà mūlākhyatārakā |

śravaṇam cānurādhā ca madhyam pūrvottarātrayam ||

bharaṇi ca maghā citrā viśākhā śatatārakā |

dhanișthāśleșikā proktā varșaveśe 'tininditāh \|

viruddhayoge tithyām ca varșaveśo na śobhanah | iti |

atra viśeșa ukto dīpikāyām |

janmarkșayuktā yadi janmamāse yasya dhruvam janmatithir bhavec ca | bhavanti tadvāsara eva nityam nairujyasaubhāgyasukhāni tasya \|

krtāntakujayor vāre yasya janmadinam bhavet |

anr̦ksayogasamprāptau vighnas tasya pade pade \|

10 viśākhā śatatārakā] viśāśetakhotatārakā N

12 tithyāṃ] viștyāṃ K T M 15 tadvāsara] taddvārata M 17 samprāptau] samprāpto T

2-3 nandā ... veśane] TLP $197 \quad 4$ 4-5 somo ... pradāḥ] TLP $196 \quad$ 6-7 aśvinī ... -āvahāḥ] TLP 193 8-9 kṛttikā ... trayam] TLP 195 10-11 bharaṇi ... 'tininditāḥ] TLP 194 


\subsection{General Methods for Gauging the Nature of the Year}

Next, the results of the calendar in the revolution of the year are summarized in Trailokyaprakāśa [197, 196, 193, 195, 194]:

The lunar dates [called] joyous, good, victorious and full are considered auspicious; the twelfth, first, and the empty [dates] are not auspicious in a revolution of the year. ${ }^{58}$ Monday, Wednesday, Thursday and Friday: these four days are excellent, but Tuesday, Sunday and Saturday bring loss and fear to the year. ${ }^{59}$ [The lunar asterisms] Aśvinī, Mrgaśīissa, Hasta, Puṣya, Punarvasu, Svāti and Revatī are auspicious in a revolution of the year; Kṛttikā, Rohiṇī, Ārdrā, Jyeșṭhā, Mūlā, Śravaṇa and Anurādhā are middling, [and so are] the three [pairs of asterisms called] 'former' and 'latter'. ${ }^{60}$ Bharaṇī, Maghā, Citrā, Viśākhā, Śatatārakā, Dhanișțhā and Śleṣikā are much condemned in a revolution of the year. ${ }^{61} \mathrm{~A}$ revolution of the year in a contrary yoga or lunar date is not favourable. ${ }^{62}$

Regarding this, a special rule is stated in the Dipikā:

If one's lunar birth date [anniversary] is joined with the asterism of the nativity, in the month of the nativity, and on the same day of the week [as the nativity], one will surely always enjoy health, good fortune and happiness. [But] one whose birthday falls on the day of Death or Mars, in a non-[natal] asterism or yoga, meets with obstacles at every step.

$5^{8}$ In either the waxing or the waning half-month ( $\left.p a k s ̣ a\right)$, the 15 tithis are termed, in order, nandā 'joyous', bhadrā 'good', jayā 'victorious', riktā 'empty' and pūrṇa 'full', repeating three times. Tithis 1 and 12 are thus exceptions to the general rule here, as they are considered inauspicious despite belonging to the nandā and bhadrā categories, respectively.

59 The first-mentioned four days are ruled by the moon, Mercury, Jupiter and Venus, respectively, considered benefic planets; the latter three are ruled by Mars, the sun and Saturn, considered malefics.

6o The six asterisms referred to are Pūrva- and Uttara-phalgunī; Pūrva- and Uttara-aṣāḍhā; and Pūrva- and Uttara-bhadrapadā.

61 Śatatārakā and Śleșikā are more commonly known as Śatabhiṣaj and Āśleșā, respectively.

62 It is not clear in what sense the word yoga is used here. 
na ṛkṣam anṛksam | kṛtāntah śaniḥ | lagnaśubhāśubhaphalam uktạ̣ hāyanasundare |

śubhagrahayute saumye varșasvāmidrśā yute | rogodvegāpadām nāśah sutadārādisampadạ̣ $\|$ deśabhūmyarthalābhaḥ syād dātā bhoktā nrpapriyaḥ| saumyam ca vipulä buddhir varșalagne śubhe śubham \| krūravarșe krūrayukte krūrāsvāmidrśáāyute | rogodvego bhayam duhkham juaro hānir daridratā $\|$ rājyabhañgaṃ tathaudāsyam svabandhukalaham kule | sthānabhramśam avāpnoti varșalagne 'śubhe 'śubham || iti |

atha varșaveśe śubhāśubhaphalajñānārthaṃ samudracakram uktaṃ viṣnuyāmale |

tiryagūrdhvagatā rekhāś catasras tatra sal̆likhet | krttikādīni rkșāṇi pūrvābdheh savyamārgatạ \| madhyāś ca sāgarāḥ khyātās tīre sāgarapārśvayoḥ| catvāraḥ parvatāḥ koṇạh pūrvādividiśaḥ kramāt \| tritribham sāgare deyam ekaikam tïrakoșthake | koṇe dvibham dvibham madhyād așțāvimiśati tārakāḥ || yatra syāj janmanakșatram tato varșaphalam labhet | māsās tu varșān māsāc ca dināni hi bhavanti vai $\mid$ duḥkham samudre sukham eva tìre śaile śriyam sallabhate manuṣyaḥ| janmarkșage ced bhavatīha varșaṃ tatrātiduḥkham kila viṣnutantre || iti |

6 saumyaṃ] saukhyaṃ T 7 krūrā-] krūra- K T M 9 rājyabhangaṃ] rātājyabhagaṃ N \| tathaudāsyaṃ] dathaudāsyaṃ B G; ddathaudāśyaṃ N $\quad 10$ avāpnoti] avāmoti $N \quad 11$ veśe] praveśe G p.c. K T M 16 vidiśah]] vidiśi K T M $\quad 20$ māsāc ca] māsādya B; māsādyā N G 22 tatrāti] tatrāpi K T M

3-10 śubha ... 'śubham] HS 101-104 
'A non-[natal] asterism' means 'not the [natal] asterism'. Saturn is [called] Death. ${ }^{63}$ The good and evil results of the ascendant are stated in Hāyanasundara [101-104]:

If a benefic is joined to good planets and to the aspect of the ruler of the year, illness, anxiety and misfortune are destroyed, and one is blessed with children, wife and so on; one gains a place, land and wealth, gives [charity], enjoys and befriends princes; there is kindness and abundant intelligence: [such is] the good [arising] when a benefic is in the ascendant of the year.

In an evil year, joined to evil [planets] and to the aspect of a malefic other than the ruler, there is fear of illness, danger, suffering, fever, loss and poverty; one meets with loss of dominion, apathy, quarrels with one's own kinsmen in the family community and a fall from one's position: [such is] the evil [arising] when a malefic is in the ascendant of the year.

Next, the Ocean diagram for knowing the good and evil results at the revolution of the year is related in the Vișnuyāmala:

Four lines go horizontally and [four] vertically. There one should write the asterisms beginning with Krrttikā counter-clockwise from the eastern ocean. The central [squares] are called oceans; the shores are either side of the oceans; the corners are four mountains: [they are] the intermediate directions in order from the east.

Three asterisms should be given to each ocean, one to each shoresquare, and two asterisms to each corner, [beginning] from the centre: [these are] the twenty-eight asterisms. One should take the results of the year from [the square] where the birth asterism falls. The months follow the year, and the days, the month.

A man meets with suffering in the ocean, happiness on the shore, and fortune on a mountain. If the year falls in the birth asterism, there is much suffering, according to the Viṣnutantra.

63 The days of 'Death and Mars' are thus Saturday and Tuesday, respectively. 


\begin{tabular}{|c|c|c|c|c|}
\hline $\begin{array}{c}\text { parvata } \\
\text { punarvasu } \\
\text { pușya }\end{array}$ & $\begin{array}{l}\text { tīra } \\
\text { ārdrā }\end{array}$ & $\begin{array}{c}\text { sāgara } \\
\text { kṛttikā rohiṇ̄ } \\
\text { mṛgaśīrșa }\end{array}$ & $\begin{array}{c}\text { tīra } \\
\text { bharaṇī }\end{array}$ & $\begin{array}{c}\text { parvata } \\
\text { revatī } \\
\text { aśvinī }\end{array}$ \\
\hline $\begin{array}{c}\text { tīra } \\
\text { āśleșāā }\end{array}$ & & & & $\begin{array}{c}\text { tīra } \\
\text { uttarabhadra- } \\
\text { padā }\end{array}$ \\
\hline $\begin{array}{c}\text { sāgara } \\
\text { maghā } \\
\text { pū. pha. u. pha. }\end{array}$ & & & & $\begin{array}{c}\text { sāgara } \\
\text { dhanișțhā śata- } \\
\text { bhișak pū. bha. }\end{array}$ \\
\hline $\begin{array}{l}\text { tīra } \\
\text { hasta }\end{array}$ & & & & $\begin{array}{c}\text { tīra } \\
\text { śravaṇa }\end{array}$ \\
\hline $\begin{array}{c}\text { parvata } \\
\text { citrā } \\
\text { svāti }\end{array}$ & $\begin{array}{c}\text { tīra } \\
\text { viśākhāa }\end{array}$ & $\begin{array}{c}\text { sāgara } \\
\text { anurādhā jyeșṭhā } \\
\text { mūlā }\end{array}$ & $\begin{array}{c}\text { tīra } \\
\text { pūrvāșāạhhā }\end{array}$ & $\begin{array}{c}\text { parvata } \\
\text { uttarāṣậ̣hāa } \\
\text { abhijit }\end{array}$ \\
\hline
\end{tabular}

varșavicāre samudracakram

atha varṣapraveśe śubhāśubhaphalajñānārtham tripatākacakram uktam muktāvalyām |

rekhātrayaṃ tiryag athordhvasaṃstham anyonyaviddhāgragam ekakoṇāt | smṛtạ̣ budhais tat tripatākacakraṃ prānmmadhyarekhäpragavarșalagnāt || nyased bhacakram kila tatra saikām

yātābdasaṃkhyām vibhajen nabhogaị |

śeșonmite janmagacandrarāśes

tulye ca rāśau vilikhec chaśänkam \|

pare caturbhājitaśeșatulye sthāne svarāśeh khacarās tu lekhyāḥ |

svarbhānuviddhe himagau tu kaștam tāpo 'rkaviddhe rug inotthaviddhe \|

3 athordhva] adhordhva B N G T $\|$ viddhā] dviddha N; piddhā K T 4 rekhāpraga] rekhāprāga B N; rekhāmuga G; rekhāgraga T M 6 yātābda] yātāha T 9 svarāśeh] śvarāse G; svarāśau K T M 10-134.1 himagau ... mahïjaviddhe] om. B N G a.c. 10 tāpo] tamo G p.c. ॥ inotthaviddhe] inātmajena K T M

3-134.2 rekhā ... sudhīmān] TMṬ 1.17-2o 


\begin{tabular}{|c|c|c|c|c|}
\hline $\begin{array}{c}\text { Mountain } \\
\text { Punarvasu } \\
\text { Pușya }\end{array}$ & $\begin{array}{l}\text { Shore } \\
\text { Ārdrā }\end{array}$ & $\begin{array}{c}\text { Ocean } \\
\text { Kṛttikā Rohin̄ī } \\
\text { Mrrgaśīrșa }\end{array}$ & $\begin{array}{c}\text { Shore } \\
\text { Bharanīi }\end{array}$ & $\begin{array}{c}\text { Mountain } \\
\text { Revatī } \\
\text { Aśvinī }\end{array}$ \\
\hline $\begin{array}{l}\text { Shore } \\
\text { Āśleșā }\end{array}$ & & & & $\begin{array}{c}\text { Shore } \\
\text { Uttarabhadra- } \\
\text { padā }\end{array}$ \\
\hline $\begin{array}{c}\text { Ocean } \\
\text { Maghā } \\
\text { Pū. pha. U. pha. }\end{array}$ & & & & $\begin{array}{c}\text { Ocean } \\
\text { Dhanișțhā Śata- } \\
\text { bhiṣak Pū. bha. }\end{array}$ \\
\hline $\begin{array}{l}\text { Shore } \\
\text { Hasta }\end{array}$ & & & & $\begin{array}{l}\text { Shore } \\
\text { Śravaṇa }\end{array}$ \\
\hline $\begin{array}{c}\text { Mountain } \\
\text { Citrā } \\
\text { Svāti }\end{array}$ & $\begin{array}{c}\text { Shore } \\
\text { Viśākhā }\end{array}$ & $\begin{array}{c}\text { Ocean } \\
\text { Anurādhā } \\
\text { Jyeșțhā Mūlā }\end{array}$ & $\begin{array}{c}\text { Shore } \\
\text { Pūrvāṣāḍhā }\end{array}$ & $\begin{array}{l}\text { Mountain } \\
\text { Uttarāṣāạhāā } \\
\text { Abhijit }\end{array}$ \\
\hline
\end{tabular}

The Ocean diagram for judging a year

Then, the Three-flag diagram for knowing the good and evil results at the revolution of the year is described in [Tājika]muktāvali[țippaṇi 1.17-20]:

Three lines go horizontally and [three] vertically, intersecting each other at the ends from one corner [to another]. The learned call that the three-flag diagram, progressing from the ascendant of the year at the central eastern line. One should inscribe the zodiac there and divide the elapsed years plus one by nine. In the sign corresponding to the remainder, [counted inclusively] from the sign occupied by the moon in the nativity, one should enter the moon. The rest of the planets should be entered in the places corresponding to the remainder, [counted inclusively] from their own signs, after dividing [the elapsed years plus one] by four.

If the moon is intersected by Rāhu, [there is] evil; affliction, if intersected by the sun; illness, if intersected by Saturn; bodily pain, if inter- 
mahïjaviddhe tu śarīrapīdā śubhaiś ca viddhe jayasaukhyaläbhaḥ| śubhāśubhavyomagavīryato 'tra phalam ca varșasya vadet sudhìmān || iti |

3

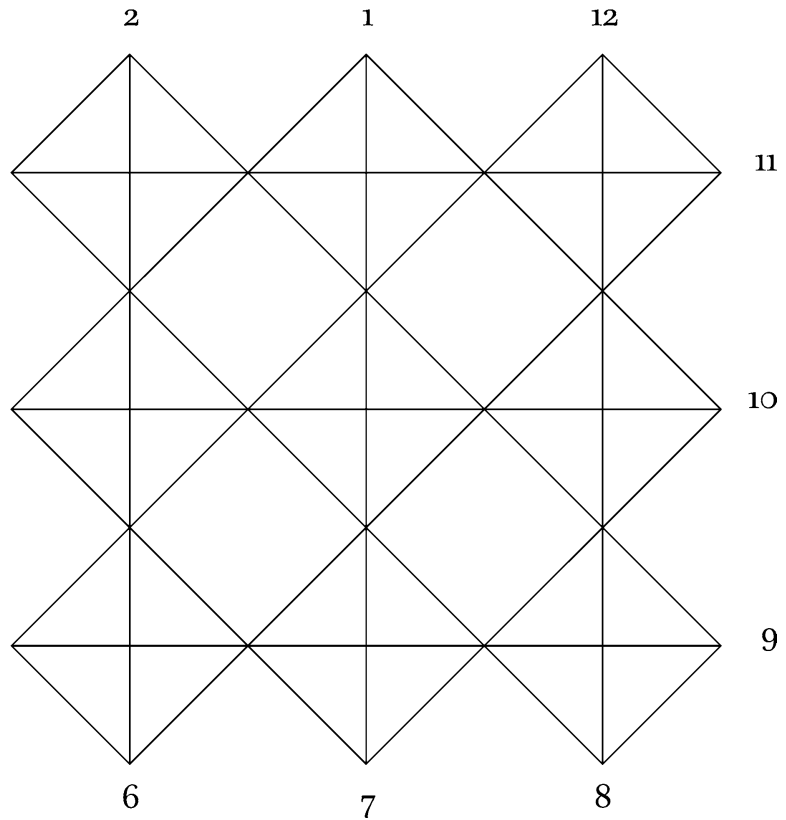

tripatākacakram

cakre meșarāśir upalakṣaṇārthaṃ likhitah | meșasthale varṣalagnaṃ jñeyam | athātra prasangād varṣaśubhāśubhaphalajñānārthaṃ svajanmalagnān meșasaṃkramalagnaphalaṃ praśnavaiṣnavoktaṃ likhyate |

janmodayād bhāsvadajapraveśalagnam hi yadbhāvagataṃ śubhānvitam | tadbhāvavrddhim prakaroti tasmin varșe nrṇām pāpayutam tad anyathā $\|$ janmodaye dehasukham dhane 'rthaläbhas trit̄̄ye ca kuțumbavrddhị| $\mid$ turye suhrtsaukhyam athātmajāptiḥ putre 'tha șașțe 'riparājayah syāt \|

3 upalakṣaṇārthaṃ] upalakṣaṇam K T || likhitaḥ] om. K T || sthale] sthāne K T || jñeyam] gneyam G 5 saṃkrama] saṃkramaṇa K T 6 bhāsvadaja] bhāsvabdaja N G \| bhāvagataṃ] bhāgavatam $\mathrm{B} N$ a.c. $\quad 8$ dhane 'rtha] nadhartha $\mathrm{N}$ nedhartha $\mathrm{G}$ a.c. \| lābhas] lābhaṃ B N G 9 suhṛt] sutat B; sut N G a.c. \| athātmajāptiḥ putre] athātre jāptih putma $\mathrm{K}$

6-136.4 janmodayād ... vilagne] PV 13.73-75 
sected by Mars; [but] victory, happiness and gain if intersected by benefics. The wise man should predict the results of the year according to the strength of the benefic and malefic planets.

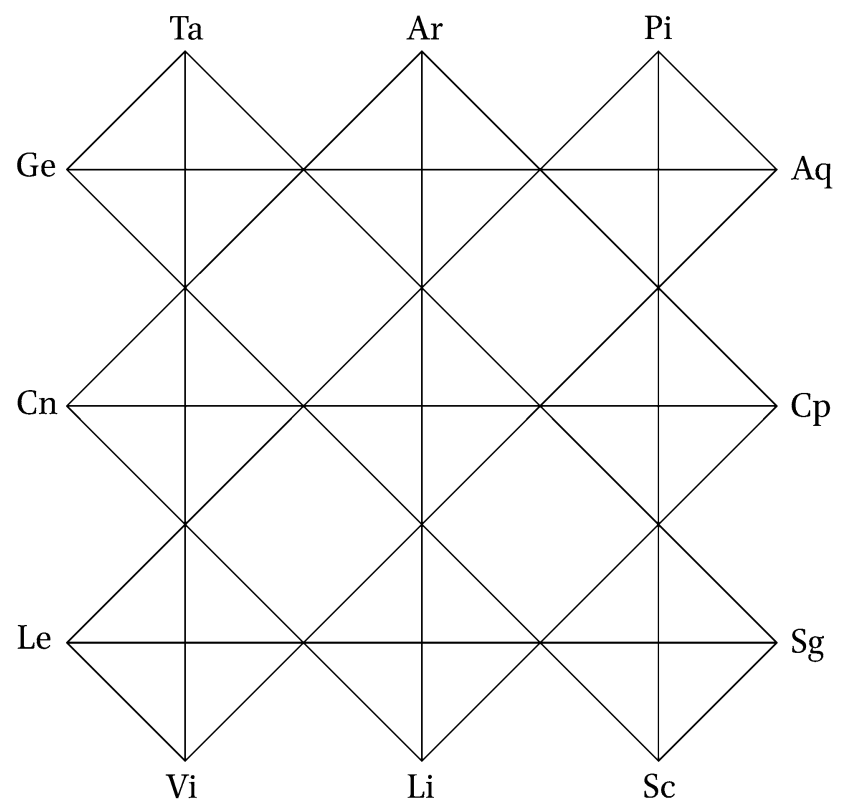

The Three-flag diagram

In the diagram, Aries has been entered as an example: the ascendant [sign] of the year should be understood to take the place of Aries. And related to that, the results of [reckoning] the ascendant at the Aries ingress from one's birth ascendant for knowing the good and evil results of the year are written [here] as described in Praśnavaiṣnava [13.73-75]:

In whatever house from the ascendant in the nativity the ascendant at the sun's ingress into Aries falls, joined to benefics, it makes [the significations of] that house prosper for men in that year. Joined to malefics, it is the reverse.

In the ascendant of the nativity [there is] bodily pleasure; in the second, gain of wealth; in the third, increase in one's household; in the fourth, happiness from friends; in the fifth, birth of a child; in the sixth, 
strīsaukhyāptir bhavati madane mrtyurugbhìs ca randhre dharmārthāptis tapasi daśame vittasaukhyāspadāptih | läbhe läbhah sukhadhanacayo duhkhhadāridryam ante pumso meșam praviśati ravau janmalagnād vilagne || iti |

etat phalaṃ saumyayute jñeyam pāpayute sarvaṃ viparītam | miśrayute $\quad 5$ miśraṃ jñeyam iti \|

meșapraveśalagnasya jagallagneti nāma yavanā vadanti | svavarșalagnāj jagallagnavicāra ukto yantrādhikāre |

janmalagnād varșalagnājjagallagnam yadā bhavet | aștame dvādaśe vāpi sa varșo na śubhāvahah \|

anyo 'pi viśeșas tatraiva |

aștame dvādaśe vāpi bhaved yatpurarāsiitaḥ |

jagallagnaṃ tadā hānis tatpurasya na saṃśayaḥ || iti |

atha janmakāle yena siddhāntena karaṇena vā makarandarāmavinodādisāranīgranthena vā grahāḥ șaṭkarmasaṃskṛtāḥ sādhitās tenaiva varṣapraveśe 'pi udayāntarādiṣațkarmasaṃskṛtāḥ spașțā grahāḥ sagatikāḥ sādhanīyāḥ | uktaṃ ca paddhatau |

4 puṃso] puṃsāṃ KT || meșaṃ] meșe KT $\quad 5$ jñeyam pāpayute] om. G 7 yavanā] yavanānāṃ G p.c. || sva] om. K T M || lagnāj] lagnād api K T M 8 vicāra] vicāro 'yam K T M 14 makarandarāma] makaraṃrādema N 
there is defeat by enemies; ${ }^{64}$ in the seventh, there is happiness from women; in the eighth, fear of illness and death; in the ninth, attainment of merit and advantage; in the tenth, gain of property, happiness and rank; in the eleventh, profit and increase of happiness and wealth; in the twelfth, suffering and poverty: [these are the results] of the ascendant when the sun enters Aries, [as reckoned] from the ascendant in a man's nativity.

These results are to be understood when [the ascendant of the year] is joined to benefics. If it is joined to malefics, all is reversed. If it is joined to mixed [planets, results] should be understood to be mixed.

The Yavanas call the ascendant at the Aries ingress by the name 'ascendant of the world'. Judging the ascendant of the world from the ascendant of one's own [revolution of the] year is decribed in the Yanträdhikāra:

When the ascendant of the world falls in the eighth or twelfth [house] from the ascendant of [one's own] nativity or from the ascendant of [the revolution of] the year, that year is not auspicious.

Another special rule [is found] in that same work:

When the ascendant of the world falls in the eighth or twelfth [house] from the sign of any town, that town suffers damage without a doubt.

\subsection{Calculating the Planetary Positions in the Annual Revolution}

Now, by whatever [astronomical] work or [abridged] manual or book of tables - such as the Makaranda, the Rämavinoda and so forth - the [places of the] planets, corrected by the six procedures, were found at the time of the nativity, the true [places of the] planets along with their motion are to be found by that same [method] at the annual revolution as well, corrected by the six procedures beginning with the correction for obliquity. ${ }^{65}$ For it is said in Paddhati[bhūṣaṇa 9]:

64 Or, possibly, of enemies; but the negative results predicted for the other two 'evil houses' support the former interpretation.

65 These six corrective procedures are presumably the four already mentioned in section 1.6 (see note 56 ) in addition to the mandaphala (equation of the centre) and síghraphala (equation of the conjunction). 
abdapraveśe khacarāḥ sacārāḥ karaṇān nijāt | sādhanīya vilagnam ca spașțam kāryam nijodayaị $\|$

te grahāḥ spașțā eva | uktaṃ ca bhāskarācāryaiḥ |

yātrāvivāhotsavajātakādau khețaih sphuțair eva phalasphuțatvam | iti |

atrādiśabdena varșapraveśādau jñeyam | tājikasāre 'pi |

vinā grahaih spaștatarair na kiṃcit

phalam pravaktum nitarām kșamaḥ syāt | iti |

atha brahmasaurāryādipakṣānāạm sattvāt kasmin pakṣe grahāḥ sādhyā ity uktam dāmodarapaddhatau |

yānti samsādhitāh khețā yena drgganitaikyatām |

tena pakșeṇa te kāryāḥ sphuțās tatsamayodbhavāḥ || iti |

nanu grahānayanam ārṣaśāstrād eva kartuṃ yujyate na tu mānuṣyāt tasyāyathārthatvād iti cet satyam | grahānayanaṃ munikṛtaśāstrād eva kartum ucitam | paraṃ tu tatrāpi kālavaśenāntaraṃ patati | uktaṃ ca sūryasiddhānte |

śāstram ādyaṃ tad evedam yat pūrvam prāha bhāskaraḥ| yugānām parivartena kālabhedo 'tra kevalah || iti |

vasișthasiddhānte 'pi |

8 saurāryādi] saurācāryādi B N G 14 tu] om. B N G a.c. 14-15 sūryasiddhānte] sūryyīseddhāṃte N 17 kālabhedo] kālābhedo N G \|| kevalaḥ] kevalam K T M

1-2 abda ... nijodayaị̣] PBh $9 \quad 4$ yātrā ... sphuṭatvam] SŚ 7.1 $\quad 6-7$ vinā ... syāt] TS 36 16-17 śāstram ... kevalaḥ] SūS 1.9 
In a revolution of the year, the [places of the] planets should be found along with their motion, from one's own manual; and the true ascendant should be found by the ascensions of one's own [location].

Those [places of the] planets are only the true ones. For it is said by Bhāskarācārya [in Siddhāntaśiromaṇi 7.1]:

In a journey, wedding, festival, nativity and so forth, true results are [found] only from the true [places of the] planets.

Here, the words 'and so forth' should be understood to include annual revolutions and so forth. ${ }^{66}$ And in Täjikasāra [36]:

Without very true [positions of the] planets one will be entirely incapable of predicting any result.

But as there are [many astronomical] schools such as the Brāhma, Saura and Ârya, according to which school should [the places of] the planets be established? Thus it is said in the Dāmodarapaddhati:

The true [places of the] planets should be established by [the method of] that school according to which they coincide with calculation by observation at that time.

If it should be objected that it is proper to base planetary calculations only on the precepts of sages and not of humans because the latter are fallible, [then we say:] true, it is appropriate to base planetary calculations only on the precepts of sages; but even in those [methods], differences creep in with time. For it is said in Süryasiddhānta [1.9]:

This is that same original science which Bhāskara taught of old. By the passing of ages, a mere difference in time [has arisen] here.

And in the Vasișthasiddhānta [it is said]:

66 This sentence testifies to the enduring love affair of Sanskrit authors with the ending $-\bar{a} d i$, its meaning in the present context being 'explained' by another compound ending in the same word. 
ittham māṇdarya saṃkṣepād uktam śāstram mayottamam | visrastī ravicandrādyair bhavișyati yuge yuge \|

visraṃsanaṃ visrastiḥ | śithilatvam iti yāvat | siddhāntasundare 'pi |

munipranite manujaị kvacic ced drśyate 'ntaram | tadā tad eva saṃsādhyam na kāryam sarvam anyathā || iti |

tad antaram bījasamjñaṃ brahmaguptamakarandamiśrādibhị̣ svasattādikāle lakṣayitvā muniśāstrajaniteșu graheșu saṃskṛtaṃ tad yuktam eva | tathā ca brahmasiddhānte |

saṃsādhya spaștataram bījạ̣ nalikādìantrebhyaḥ|

tatsamskrtagrahebhyah kartavyau nirnayādeśau \|

ity alam | atha pañcāngapattrād eva tātkālikīkaraṇena spașțagrahānayanam uktaṃ śrīmannīlakaṇțhadaivajñaiḥ |

gataisyadivasādyena gatir nighnī khașaḍ̣hrtā| labdham aṃśädikaṃ śodhyam yojyam spașțo bhaved grahaḥ || iti |

atha pañcāngīyanakṣatrād eva candraspașțīkaraṇam uktaṃ tair eva |

itarkṣanādyah kharaseșu śuddhāḥ sūryodayād iștaghațīṣu yuktāh | bhayātasaṃjñā bhavatīha caivaṃ nijarkșanāḍā sahito bhabhogậ \|

1 mayottamam] mayoditam K T M 4 ced] ca K T M \| 'ntaram] taram B N G 5 tad eva] deteve N 6 brahma] trahma N 7 graheșu] om. B N G a.c. 9 saṃsādhya] saṃsādhyam M 11 pattrād] yaṃtrād K T M \| karaṇena] karaṇenya B N G 12 śrīman] śrī B N G $\quad 15$ eva $^{2}$ ] ādau bhabhogabhayātam āha add. G $\quad 16$ itarkṣa] gatarkșa T $\quad$ 16-17 itarkṣa ... bhabhogah] om. B

4-5 muni ... anyathā] SiS 2.1.9 13-14 gataișya ... grahah] ST 1.18

16-17 itarkșa ... bhabhogah] Although this stanza is omitted by the base text as well as by available editions of the ST, its presence in all other witnesses of the Hãyanaratna (including one earlier than the base text), in conjunction with Balabhadra's close connection with Nillakanthha's family, makes me inclined to regard it as a genuine quotation from the ST, lost from at least some traditions of that text. It may even have been deliberately excluded from B to agree with what the copyist regarded as the standard reading of the ST. 
Thus, Māṇdavya, have I told you [this] excellent science in brief. A fallaway of the sun, moon and other [planets] will come to pass from age to age.

'Fall-away' [means] a falling away, that is to say, a loosening. And in Siddhāntasundara [2.1.9 it is said]:

If humans occasionally see a difference in [observed phenomena and the methods] authored by sages, then only that should be remedied: not everything should be changed.

That difference, known as a 'seed', has been defined by Brahmagupta, Makaranda Miśra and others in their respective epochs as a correction to the [positions of the] planets generated by the precepts of the sages; and that is proper. So too [it is said] in the Brahma[sphuța] siddhānta: ${ }^{67}$

After defining the 'seed' very precisely with the help of instruments such as the nalika , [astrological] judgement and prediction should be based on the [positions of the] planets corrected by that [value]. ${ }^{68}$

Let this suffice. Next, [in Samjjñätantra 1.18] the illustrious Nīlakaṇtha Daivajña describes the calculation of the true [places of the] planets by interpolation from just a page of the calendar:

The motion [should be] multiplied by the days and so forth elapsed [or] yet to come and divided by sixty. The result in degrees and so forth should be subtracted [or] added: [this is] the true [place of the] planet.

Then [in Samjñätantra 1.19] he himself describes how to find the true [position of the] moon merely from the [lunar] asterism given in the calendar:

The [time in] nādīs of [the moon leaving] the previous asterism subtracted from sixty and added to the ghațis sought from sunrise is known as the traversed part of the asterism; likewise, added to the nädīs of [the

67 While several later sources similarly attribute this stanza to the Brahmasphutasiddhānta, possibly on the authority of Balabhadra, it is not found in standard editions of that work. It may simply be misattributed, or else derive from a different work called Brahmasiddhānta.

68 For the nalikā- or nalaka-yantra, see Rai 2000. 
khaṣaḍhnam bhayātam bhabhogoddhṛtam tat

khatarkaghnadhiṣnyeșu yuktam dvinighnam |

navāptam śaśi bhāgapūrvas tu bhuktị

khakhābhrāṣtavedā bhabhogena bhaktāh || iti |

atredaṃ dhyeyam | pañcāngīyā grahāḥ kiṃdeśīyā utpannaś ca manuṣyah kiṃdeśīyah | na hi sarvadeśīyamanuṣyānāām ekadeśaniṣpannapañcāngena spaștā grahāḥ kartum yujyante deśabhedena | deśāntarabhujāntarodayāntaracarapalādisaṃskārasadbhāvāt sūryādisarvagrahāṇām anyathādarśanāt | tasmāt spaștagrahasahitais taddeśīyapañcāngaị kṛtvā taddeśīyamanuṣyāṇāṃ spaṣṭā grahāḥ kartum iṣyante na tv anyatreti jñeyam ||

atha lagnādidvādaśabhāvasādhanam | uktaṃ ca tājikasudhānidhau ||

janmābdaprcchādiśubhāśubheșu bhāvā vidheyāh sudhiyāyato 'tra| tattadvaśenaiva diśanti nityam śubhāśubham bhāvabhavam nabhogāh || iti |

7 bhedena | deśāntara] bhedeśāntara N 11 tājika] jātaka K T M

1-4 khaṣaḍghnam ... bhaktāḥ] ST 1.19 12-13 janmābda ... nabhogāḥ] TYS 2.18 
moon leaving] the current asterism, it becomes the duration of [that] asterism. ${ }^{69}$

The traversed part of the asterism multiplied by sixty and divided by the duration of the asterism, added to the [number of elapsed] asterisms times sixty, multiplied by two and divided by nine, is the [position of the] moon in degrees and so forth ${ }^{70}$ its motion [per ghațī] is fortyeight thousand [seconds of longitude] divided by the duration of the asterism.

Here the following should be considered: for what place were the [positions of the] planets in the calendar [calculated], and in what place was the person born? For it is not proper for the true [positions of the] planets [in the nativities] of persons [born] in every place to be taken from a calendar produced for a single place, on account of the difference between places. For the sun and all other planets appear differently [in different places] on account of corrections for longitude, eccentricity, obliquity, palas of ascensional difference and so forth. ${ }^{71}$ Therefore it should be understood that it is right for the true [positions of the] planets to be taken from a calendar made for a certain place, furnished with the true [positions of the] planets, [for use in nativities] of persons [born] in that place, and not [from] anywhere else.

\subsection{Calculating and Judging the Houses in the Annual Revolution}

Now, establishing the twelve houses beginning with the ascendant. And it is said in Täjika[yoga]sudhānidhi [2.18]:

For [knowledge of] the good or evil in a nativity, [revolution of a] year, question, and so forth, the wise [astrologer] should establish the houses, for the planets always signify the good or evil produced by the houses on account of this or that.

69 This verse is not found in available editions of the Samjiñatantra. The calendar ( pañcānga) shows, for each day (beginning at sunrise and divided into 6o ghațis or nādīs), the 'break' (cheda) or time at which the moon changes asterisms (naksatra). The previous day's cheda subtracted from 6 o will thus give the time spent by the moon in the current asterism before sunrise on the current day.

70 The implied starting-point is $0^{\circ}$ sidereal Aries, also the beginning of the asterism Aśvinī. The formula $60 \times 2 / 9$ gives $13^{\circ} 2 \mathrm{O}^{\prime}=48, \mathrm{ooo}$ ", the extension of one asterism.

71 Strictly speaking, the eccentricity and obliquity of the ecliptic do not vary with the place of observation. 
tājikatilake 'pi |

bhāvasādhanam athābhidhīyate hāyanotthaphalanirnayahetọ̣| praśnayānajanivarșaveśane bhāvasādhanam avādi kāraṇam || iti |

bhāvānāṃ nāmāny uktāni tājikamuktāvalyām |

tanur dhanaṃ bhrātṛsuhṛtsutāristrïrandhradharmāh kramaśo vilagnāt | vyāpāralābhavyayasamjiñakāś ca saṃhāragatyā syur ime 'rkatulyāh || iti |

atra lagnādibhāvā anvarthasaṃjñā jñeyāḥ | yathā dehavicāro lagnāt dravyavicāro dvitīyād evaṃ sarvatra | etat saviśeșaṃ bhāvavicāre vakṣyāmah || tatra bhāvānayanopayuktaṃ carakhạ̣ḍadinārdhānayanam |

syāt sāyane 'rke 'jatulādiyāte śan்kuprabhā svadyudale 'kșabhā sā| tridhākșabhā diggajadigvinighnī tv antyā trihṛt syuś carakhaṇdakāni $\|$ syāt sāyanoṣnāṃśubhujarkșasaṃkhyacarārdhayogo lavabhogyaghātāt | khāgnyāptìyuktas tu caraṃ palādi șaștyā vibhaktam ghațikädikam syāt || carena saṃyutonāś ca kartaryās tithinādikāḥ|

3 praśnayānajani] janmayānakhalu B N G a.c.; praśnayānakhalu G p.c. || avādi] athādi K T M 9-146.2 tatra ... bhavet] om. B N G a.c. 9 bhāvānayanopayuktaṃ] bhāvanayanopāyam uktam K T; bhāvanayanopāya uktah || atha M 10 syāt] syāyat G p.c. || 'kṣabhā sā] kṣabhāsāṃ M

5-6 tanur ... tulyāh] TM 16

72 The word used for 'twelve' literally means 'sun'. The order of the houses follows that of the zodiacal signs, which is the reverse of the daily course of the sun across the sky: beginning at sunrise, it passes first through the twelfth house, then the eleventh, etc.

73 Cf. note 24.

74 These increments of ascensional difference (carakhanda) are given in units of time (pala, approximately 24 seconds of clock time); multiplication by 6 would give asus, corresponding to minutes of arc. The purpose of these three values is to adjust the equatorial rising times, or right ascensions, of the zodiacal signs (in the tropical zodiac) for the terrestrial latitude of observation: the first and largest value is subtracted from the rising times of Aries and Pisces but added to those of Virgo and Libra; the middle value is subtracted from Taurus and Aquarius but added to Leo and Scorpio; and the final, smallest value is subtracted from Gemini and Capricorn but added to Cancer and Sagittarius. 
And in the Täjikatilaka:

Establishing the houses is described next, in order to judge the results produced by [the revolution of] the year. In a question, journey, nativity, or annual revolution, establishing the houses is said to be the foundation.

The names of the houses are given in Tājikamuktāvali [16]:

They are known in order from the ascendant as body, wealth, brothers, friends, children, enemies, wife, wound, piety, occupation, gain, and loss, numbering twelve, in reverse order. ${ }^{72}$

These names of the ascendant and other houses should be understood to reflect their meanings, so that [the topic of] the body is judged from the ascendant, wealth is judged from the second [house], and so on throughout. We shall explain this in detail in [the chapter on] the judgement of houses.

In that connection, the increments of ascensional difference and diurnal semi-arcs employed in the calculation of houses are calculated [as follows]:

When the sun with precession added is at the beginning of Aries or Libra, the shadow of the gnomon at local noon will be the shadow of latitude. ${ }^{73}$ The shadow of latitude multiplied three ways: by ten, eight, and ten, [respectively], and the last [figure] divided by three, gives the increments of ascensional difference. ${ }^{74}$

Half the sum of the ascensional difference of the number of signs in the argument of the sun with precession added, added to the product of the degrees remaining [in that argument] divided by thirty, is the ascensional difference in palas and so forth; divided by sixty, it is [the same] in ghațis and so forth. ${ }^{75}$

The ascensional difference should be added to or subtracted from fifteen $n \bar{a} d \bar{l} \bar{s}$ when the sun with precession added is in the six signs

75 The object of this exercise is to find the time between sunrise and local noon (the culmination of the sun) from the rising times of the zodiacal signs. The rising times of the signs, with fractions, between the zodiacal position of the sun and its opposite point in the zodiac will give the length of the day; half that time will give the time of noon. However, as the linear interpolation included in the method falsely presumes a zodiacal sign to rise at a uniform speed, its result will only be approximately correct. 
meșajūkādișaḍhe 'rke sāyane sto divādale |

dinārdham trị̣śatah śuddham śeșam rātridalam bhavet \|

atha natādīnām ānayanam uktam sakalasiddhāntamaṇ̣alīsaroviharaṇarājahaṃsagaṇitavidyācāturītāntrikapañcānanāhigavīpravinnaiḥ śrīmadgurucaraṇaiḥ paddhaticintāmaṇau | tatrādau natonnatānayanam |

dinārdhayugrātrigatāvaśeșa-

nādyo natam paścimapūrvakam syāt |

dyuyātahīnaṃ dyudalaṃ natam prāg

dyukhaṇdahinam dyugatam param tat $\|$

athāyanāṃśānayanam |

\section{bhūnetravedonaśako daśāmśahīna hhaṣaḍhir vihṛto 'yanāṃśah | trighno 'rkarāsìn svadalena yuktas tāvanmitābhir vikaläbhir ạdhyaḥ \|}

atha spașțalagnānayanam | tatra spașțalagnānayanopayuktam svodayasādhanaṃ brahmatulye |

1 bhe'rke] bhakte KTM $\|$ sto] ste KTM 4-5 śrīmadgurucaraṇaih] om. KTM 9 hīnaṃ] hīne K T M 13-148.7 tatra ... sādhanam] om. B N G a.c.

76 As local noon and midnight are always 30 ghațis (12 hours) apart, the difference between half the duration of a day (the sun's diurnal semi-arc) and 30 will give half the duration of a night (its nocturnal semi-arc).

77 While hamsa etymologically corresponds to the English word goose, both hamsa and the räjahamsa used here have a wider range of meaning, being applied to several species of large, typically white aquatic birds. The translation 'swan' in this context reflects the cultural and symbolic status of the (räja)hamsa rather than ornithological taxonomy.

78 The unusual compound employed by Balabhadra to express 'the grammar of Patañjali' literally translates as 'the cattle of the serpent', thus adding two more zoological allusions to this passage. Patañjali is traditionally identified as an avatāra or incarnation of Ananta, the divine serpent on which Viṣnu reclines.

79 Strictly speaking, these four definitions all pertain only to the upper meridian distance (nata). The lower meridian distance (unnata) will be the difference between the former and $180^{\circ}$. 
beginning with Aries or Libra: [these] are the diurnal semi-arcs. [When] the diurnal semi-arc subtracted from thirty, the remainder is the nocturnal semi-arc. ${ }^{76}$

Next, the calculation of meridian distance and so forth is described by the royal swan ${ }^{77}$ roaming the lake encompassing all [astronomical] schools, the lion among those who have mastered the subtleties of the science of mathematics, the expert in the grammar of Patañjali, ${ }^{78}$ our illustrious and venerable teacher [Rāma Daivajña], in the Paddhaticintāmaṇi; and first, calculating the upper and lower meridian distance:

[By night], the nādīs elapsed or remaining of night added to [those of] the diurnal semi-arc will be the western or eastern meridian distance [of the sun, respectively]. By day, the diurnal semi-arc minus the elapsed [nâdīs of] day is the meridian distance in the east; minus the remaining [nādīs of] day, the one in the west. ${ }^{79}$

Next, calculating the precessional value: ${ }^{80}$

The Śaka year minus four hundred and twenty-one, less by one tenth and divided by sixty, is the degree of precession, added to as many seconds of arc as three times the [number of] signs [traversed by] the sun, increased by half. ${ }^{81}$

Next, calculating the true ascendant; and how to find the oblique ascensions employed in the calculation of the true ascendant [is described] in Brahmatulya $[3.1-2]:{ }^{2}$

8o Presumably this and the remaining unattributed quotations in this section are all taken from Rāma Daivajña's Paddhaticintāmaṇi.

81 The epoch of $o^{\circ}$ sidereal Aries coinciding with the vernal equinox is thus set to Śaka 471 or $549 \mathrm{CE}$, and the annual rate of precession estimated at 54 seconds of arc - considerably less than the one minute stated by Balabhadra in section 1.6 above (perhaps meant only as an approximation) but still greater than the modern value of 5 o seconds. For the time of the completion of the Hāyanaratna on 14 April (Gregorian or New Style), 1649, corresponding to Śaka 1571, the first part of the calculation would be: (1571 - 421) $\times 0.9 / 60=17.25$ or $17^{\circ} 15^{\prime}$. By modern calculation, the sun at sunrise in Rajmahal was at $24^{\circ} 19^{\prime} 40^{\prime \prime}$ Aries in the tropical zodiac and had therefore traversed about o.81 signs, giving an additional $0.81 \times 3 \times 1.5=3.645$ seconds of arc, or all in all $17^{\circ} 15^{\prime} 04^{\prime \prime}$ (rounded). The sidereal longitude of the sun at sunrise would thus be $7^{\circ} \mathrm{O} 4^{\prime} 36^{\prime \prime}$ Aries.

82 An alternative title for Bhāskara II's Karanakutūhala. 
lan்kodayā nāgaturañgadasrā

go'ñkāśvino rāmaradā vinādyaḥ|

kramotkramasthāś carakhaṇdakaị svaị̣

kramotkramasthaiś ca vihinayuktāḥ|

meșādișaṇnām udayāḥ svadeśe

tulādito 'mī ca vilomasamsthāḥ \|

atha lagnasādhanam |

yatkālārkah sāyanas tasya bhogyair

bhāgair nighnạ̣ svodayaḥ khāgnibhaktaḥ|

bhogyam jahyād iștanāḍ̄palaughāc

cheșād agryān svodayāmés cāvaśeșam \|

triṃśannighnam aśuddhāptam bhāgādyam meșapūrvakaih |

aśuddhāt prāg grhair yuktạ̣ lagnam syād vyayanāmnśakam ||

bhogyālpakālāt khatrighnāt svodayāptalavādiyuk|

ravir eva bhavel lagnaṃ saṣaḍbhārkān niśā tanụ̣ \|

atra janmadeśīyameșādilagnamānair lagnaspașțikaraṇaṃ kartavyaṃ na tv anyadeśodayair iti | atha dhanarṇalagnānayane viśeșah |

sūryodayādyātaghațișu bhogyair

divāvaśeșe sarasārkabhuktaih |

niśāgate 'py añgayutārkabhogyair

niśāvaśeșe ravibhuktabhāgaih |

gatāgatai rāśyudayaị̣ khabhoktyā

lagnam dhanarnam samam eva bhüyāt || iti |

3 kramot-] kramāt M 4 kramot-] kramāt K T M 8 yat] tat B N G T 10 palaughāc] palebhyaḥ K T M 11 agryān] agryāt B N G 13 g̣̣hair] grahair G M $\quad 17-23$ atha ... iti] om. B N G a.c. 17 dhanarṇa] dhanarṇe M 19 sarasārka] rasabhārka K T M 20 'py añga vyanga $\mathrm{K}$ T M

1-6 lankkodayā ... saṃsthāḥ] KK 3.1-2

83 The object here is to find the rising sign and degree at any time from the time of local sunrise and the rising times of the zodiacal signs, with fractions. Again, the method is approximate because a zodiacal sign is falsely presumed to rise at a uniform speed. Adding six signs to the longitude of the sun means using the point $180^{\circ}$ opposite in the zodiac.

84 The meaning of the last clause is uncertain, but the main point of the quotation is always to use the horizontal distance in the east. Between noon and midnight, when 
The right ascensions are two hundred and seventy-eight, two hundred and ninety-nine, and three hundred and twenty-three vinädīs in direct and reverse order. Subtracted from and added to the respective increments of ascensional difference, [also] in direct and reverse order, they are the ascensions of the six [signs] beginning with Aries for one's own location. Beginning with Libra, these are inverted.

Then, finding the ascendant:

The oblique ascension [of the sign] where the sun with precession added is at the time is multiplied by the degrees yet to be traversed [in it] and divided by thirty. One should subtract [this] part yet to be traversed from the total [time] sought in $n \bar{a} d \bar{c} \bar{s}$ and palas, and the oblique ascensions [of the] following [signs] from the remainder. The [resulting] remainder, multiplied by thirty and divided by [the oblique ascension of the sign] not subtracted, added to the houses - Aries and so forth - prior to the one not subtracted and minus the precessional value, is the ascendant in degrees and so on. [With only] a little time remaining [from sunrise to birth, that time], multiplied by thirty and divided by the oblique ascension [of the sun's sign], added in degrees and so on to [the longitude of] the sun itself is the ascendant. At night, the ascendant [is calculated] from [the longitude of] the sun with six signs added. ${ }^{83}$

This procedure of finding the true ascendant should be performed using the durations of Aries and the other ascendant [signs] for the place of birth, and not the ascensions for any other place. Next, a special rule for calculating the ascendant by addition or subtraction:

By the [degrees] yet to be traversed [by the sun] in the ghațis following sunrise; by the [degrees] traversed by the sun with six [signs] added at the end of day; by the [degrees] yet to be traversed by the sun with six [signs] added when night has fallen; by the degrees traversed by the sun at the end of night: increased or decreased by the ascensions of the signs elapsed and not elapsed, the ascendant will be the same as [the figure] declared from the culminating sign. ${ }^{84}$

the sun is in the western hemisphere, its opposite point in the ecliptic is used for finding the ascendant. 
atha daśamalagnānayanam |

yuktāyanāmessārkagataișyabhāgā lan்kodayaghnāh khagunoddhṛtās tat | syād bhuktabhogyam tapanasya jahyāt palīkrtāt prāgaparān natāt tat || kramād gataișyān udayāṃś ca śeșam aśuddhahṛt khāgnigunam lavādyam | viśuddhapūrvāparabhe vihīnayutam khabhaṃ syād ayanāṃśahinam \| lagnam saṣaḍhham madanābhidhānam turyābhidhaṃ syād daśamāt saṣaḍbhāt ||

atha pūrvanate 'pi dhanalagnānayanārtham madīyaṃ vṛttam |

prān natasyonnataṃ kṛtvā raviṃ kṛtvā sașaḍbhakam | lan̉kodayair dhanākhyena karmaṇā syāt khabhasphuțam ||

atha natạ̣ vinaiva lagnād eva daśamalagnasādhanam uktạ̣ vivāhavịndāvane |

krtvā lagnād arkavad rātrikhaṇdam bhūyo vyakșais tadghațībhir vilagnam | cakrārdhone te ca tatkālam evam jāyeyātām astamadhyāhnalagne || iti |

8 lagnānayanārthaṃ] lagnārthaṃ B N G a.c. 10 khabhasphuțam] sphuṭaṃ khabhaṃ G p.c. 13 vyakșais] vyaktais B N G 14 cakrārdhone] cakrārddho 6 na K; cakrārddho 6 nam M $\|$ iti] om. B

13-14 kṛtvā ... lagne] VV 8.1 
Next, calculating the tenth house cusp:

The degrees traversed or yet to be traversed by the sun with precession added, multiplied by the right ascensions [of the respective signs] and divided by thirty, will be [the time] elapsed or yet to elapse [in the diurnal path] of the sun. One should subtract that from the eastern or western meridian distance converted to palas, respectively, and [likewise subtract] the ascensions [of the signs] traversed or yet to be traversed. The remainder [of the meridian distance], divided by the [ascensions of the signs] not subtracted and multiplied by thirty, are the degrees and so on [which], subtracted from or added to the eastern or western signs that have been subtracted, will be the culminating sign [and degree] when the degree of precession has been subtracted. 85

The ascendant with six signs added is called the seventh house; [the sign] six signs from the tenth is called the fourth.

Now a stanza of my own on calculating [the midheaven by] addition to the ascendant from the meridian distance in the east:

Having found the complement of the meridian distance in the east and added six signs to [the longitude of] the sun, the cusp [within] the culminating sign is derived by the procedure called addition by right ascensions.

Next, how to derive the tenth house cusp from the ascendant itself, without the meridian distance, is described in Vivāhavrndāvana [8.1]:

After establishing the nocturnal semi-arc for the ascendant as if it were the sun, and then the ascendant from its ghațis without terrestrial latitude, with half the circle removed they will thus become, at that time, the descendant and [upper] meridian cusps.

85 Once more an approximate method based on the presumption that all degrees of a given zodiacal sign rise at a uniform speed. 
ayam arthah | prathamaṃ svābhīṣțakāle svadeśīyodayair lagnam kāryam | tatas tad eva lagnaṃ daśamalagnārtham sūryam kalpayitvā ayanāṃśāḍhyabhānor iti vakṣyamāṇavidhinā caradalam āneyam | tatạ̣

\section{carapalayutahīnā nādikāḥ pañcacandrā}

dyudalam atha niśārdham yāmyagole vilomam |

iti rātridalam āneyam | tato rātridalam eveșțakālaṃ prakalpya prāg ānītam lagnam arkaṃ kalpayitvā vyakṣair lan̉kodayair uktaprakāreṇānītaṃ lagnaṃ caturthalagnam bhavati | atha te prāglagnacaturthalagne șaḍrāśyūne krameṇa saptamadaśamalagne bhavetām ||

atha lagnacaturthayoḥ siddhau sasaṃdhisarvabhāvānayane matkṛtapadyāni |

lagnaṃ caturthāt saṃśodhya śeșaṃ șạ̣bhir vibhājitam | rāśyādyam yojayel lagne saṃdhị syāl lagnavittayoḥ || saṃdhị șaḍamśasamyukto dhanabhāvo bhavet sphuțah | dhanabhāvaḥ șạ̣aṃsaạ̣hyaḥ saṃdhir dhanatṛtīyayoh || șạạạśasamyutạ̣ saṃdhis tṛtīyo bhāva ucyate | șaḍaṃśāḍhyas tṛtiyaḥ syāt saṃdhir bhrātṛcaturthayoh || tṛtīyasaṃdhir ekāḍhyas turyasaṃdhir bhaved iha | dvyāḍhyas tṛtīyabhāvo 'pi putrabhāvo bhavet sphuțạ || tryāḍhyo dvitīyasaṃdhị syāt saṃdhị pañcamabhāvajạ̣ | dhanabhāvo vedayuto ripubhāvah prajāyate \| lagnasaṃdhị̣ pañcayutạ̣ saṃdhị syād ripubhāvajạ̣| lagnādyāḥ saṃdhisahitāḥ bhāvāḥ ṣaḍrāśisaṃyutāḥ | saptamādyā bhavantīha bhāvāḥ sarve sasaṃdhayaḥ || iti |

3 vakṣyamāṇavidhinā] om. KTM 7 kalpayitvā] prakalpayitvā G 8 caturthalagne] caturthe K T M 13 rāśyādyaṃ] rāśyādi K T 20 tryāạhyo] āạhyo G K T M

9 bhavetām] G adds in a different hand in the margin: atra proktaprakāāāitacaturthalagnasya carodayādīnām avayavatyāgāt kadācit sāṃtaratā bhavatīti jñeyam. . 20 tryāḍhyo] The variant of G K T M is almost certainly due to the conjunct character tryā being misread as the similar-looking independent $\bar{a}$ of the so-called Calcutta or northern style of Devanāgarī. 
The meaning is as follows: first the ascendant for the time sought should be found using the [oblique] ascensions for one's own place. Then, imagining that same ascendant to be the sun for the sake of [finding] the tenth cusp, half the ascensional difference should be calculated by the rule beginning 'Of the sun with precession added', stated below. ${ }^{86}$ Then the nocturnal semiarc should be calculated as follows:

The palas of ascensional difference added to or subtracted from fifteen $n \bar{a} d \bar{l} \bar{s}$ are the diurnal and nocturnal semi-arc, [respectively]; vice versa in the southern hemisphere.

Then, imagining the nocturnal semi-arc to be the time sought, and imagining the previously calculated ascendant to be the sun, the ascendant, calculated by the method described as 'without latitude', [that is], by right ascensions, becomes the fourth cusp. Next, this eastern ascendant and fourth cusp minus six signs will be the seventh and tenth cusps, respectively.

Next, once the ascendant and the fourth [house cusp] have been found, [here are some] verses of my own making on calculating all the houses with their junctions:

Subtracting [the ecliptical longitude of] the ascendant from [that of] the fourth, one should add the remainder in signs and so forth, divided by six, to the ascendant: [the result] will be the junction of the ascendant and the second house. [That] junction with [another] sixth added will be the cusp of the second house; the second house with one sixth added is the junction of the second house and the third. [That] junction with one sixth added is called the third house; the third with one sixth added is the junction of the third and fourth houses. The junction [following] the third with one [sign] added will be the junction [following] the fourth, and [the cusp of] the third with two [signs] added will be the cusp of the fifth house. The junction [following] the second with three [signs] added will be the junction following the fifth house; [the cusp of] the second house with four [signs] added will become [the cusp of] the sixth house. The junction [following] the ascendant with five [signs] added will be the junction following the sixth house. When added to six signs, [these six] houses beginning with the ascendant, along with their junctions, become all the [remaining] houses beginning with the seventh, with their junctions.

86 This exact phrase does not recur anywhere in the Hāyanaratna. Presumably Balabhadra intended to quote one work on the topic but forgot and quoted another instead. 
atha kevalalagnajñānād eva sakalabhāvasaṃdhisādhanārthaṃ sugamopāyo matkṛtah |

sveștalagnād vakṣyamāṇavidhinā caram ānayet |

lagne meșādișațkasthe tenonās tithināḍikāḥ ||

tulādiṣaḍbhe sahitāḥ prakalpyās te 'ṃśakāḥ punạ̣ |

tair aṃśaị sahitam lagnaṃ lagnasaṃdhir bhavet sphuțạ \|

tadamśaị̣ sahitạ̣ saṃdhir dhanabhāvaḥ prajāyate |

dhanabhāvas tu tair yukto dhanasaṃdhị prajāyate ||

tair yukto dhanasaṃdhiś ca bhrātṛbhāvo bhavet sphuṭah |

taiḥ saṃyuto bhrātṛbhāvaḥ saṃdhị̣ syāt sahajābhidhạ̣ ||

tṛtīyasamdhis tair yuktas turyabhāvah prajāyate |

pūrvoktavat samprasādhyāḥ śeșā bhāvāḥ sasaṃdhayaḥ || iti |

bhāvaphalavicāra uktah śrīmannīlakaṇțhadaivajñaih |

khețe saṃdhidvayāntahsthe phalam tadbhāvajam bhavet |

hīne 'dhike dvisaṃdhibhyām bhāve pūrvāpare phalam \|

anyatrāpi |

ārambhasaṃdher dyucaro yadonaḥ phalaṃ dadāty ādimabhāvajātam | virāmasaṃdher adhikas tadānīm āgāmibhāvotthaphalapradah syāt || iti |

atredam avagantavyam | yadā kadācid ekarāśir bhāvadvaye samāyāti athavā bhāva ekarāśị̣ parityajyāyāti tadā bhāvakuṇụalyāṃ tādṛsāā eva rāśayaḥ sthāpyāḥ | saṃdhirāśyāditulyo grahạ̣ pūrvāparabhāvasaṃdhistha-

\footnotetext{
1 jñānād] jñād B || saṃdhi] rāśi K T M 4 șațkasthe] șaḍbhasthe K T M $\quad 5$ șaḍbhe] șaḍbhaih M 6 saṃdhir ... sphuțaḥ] sandhiḥ prajāyate K T M $\quad 7$ tadaṃśaị sahitạ̣ saṃdhir] tair yuto lagnasandhiś ca K T M || bhāvaḥ prajāyate] bhāvo bhaved iha K T M 8 dhanabhāvas tu tair yukto] tair yukto dhanabhāvaś ca K T M 9 sphuțaḥ] sphuțam K T M $\quad 12$ samprasādhyāḥ] prasaṃsādhyāś K T; prasamsāâdhyāḥ M 13 phalavicāra uktaḥ] vicāraphalam uktaṃ K T M || śrīman] śrī B N G 17 dadāty] vṛdaty B N a.c. G; dadaty N p.c. $\quad{ }^{18-156.3}$ iti ... bhāva] om. N G $\quad 20$ bhāva $\left.^{1}\right]$ om. K T M \| parityajyāyāti] scripsi; parityajya yāti B; parityajyāvāyāti K T; parityajya vā yāti M \| tadā] tathā K
}

14-15 khețe ... phalam] ST 1.28

19-156.2 atredam ... prāñcah] G indicates that this passage should be inserted before rather than after the foregoing quotation. 
Next, [here is] an easy method devised by myself for finding all the houses with their junctions merely from the knowledge of the ascendant:

From the ascendant [at the time] sought one should find the ascensional difference by the method described below: if the ascendant is in the group of six [signs] beginning with Aries, fifteen nādīs are made less by that [amount]; but if in the six signs beginning with Libra, those degrees should be understood to be added [to fifteen $n \bar{a} d \bar{\imath} \bar{s}$ ]. The ascendant added to those degrees will be the exact junction [following] the ascendant. [That] junction added to those degrees becomes [the cusp of] the second house, and the second house added to them becomes the junction [following] the second house. The junction [following] the second house added to them will be the cusp of the third house, and the third house added to them will be the junction named after the third house. The junction [following] the third [house] added to them becomes [the cusp of] the fourth house. The remaining houses with their junctions are to be found as previously described.

The judgement of the results of a house is described by the illustrious Nīlakaṇtha Daivajña [in Saṃjñätantra 1.28]:

When a planet is placed between two junctions, [its] results will be produced by that house. If [its longitude] is less or greater than the two junctions, [its] result [will belong] to the former or latter house, [respectively].

And elsewhere [it is said]:

When [the longitude of] a planet is less than the beginning junction, it gives results produced by the previous house. If it is greater than the ending junction, then it will give results produced by the following house.

Here the following is to be understood: whenever one sign extends over two houses, or a house extends over more than one sign, then that is how the signs should be entered in the figure of houses. A planet whose [longitude in] signs and so forth equals a [house] junction should be entered exactly on the line marking the junction between the former and the latter house. But 
rekhāyām eva sthāpyaḥ | atha bhāvakuṇ̣alī kevalaṃ bhāvaphalārtham eva | anyaḥ sarvo 'pi tājikavicāro grahakuṇ̣alyaiva vidheya iti prāñcạ || atha bhāvaviṃśopakānayanam uktaṃ muktāvalyām |

grahasaṃdhyantaram bhāvasaṃdhyantaravibhājitam | labdham bhāvaphalam jñeyam tattribhāgo viśopakāh ||

atrāntarakaraṇe viśeșa uktaḥ paddhatau |

ädyasamidhir grahād bhāvāc chodhyo bhāvonake grahe | bhāvasthasaṃdhitah śodhyo graho bhāvas tathādhike \|

bhāvatas tu phalaṃ sarvam janmavarșavratādiṣu | viṃśopakānumānena gamanapraśnavāstuṣu \|

atha kīdṛso bhāvo grahasamyogena śubham aśubhaṃ vā phalạ̣ prayacchatīty uktam tājikatilake |

nijapatiguruvitsurāripūjyair yadi sahitaś ca vilokitaḥ sa bhāvaḥ| atiśayaphalado na śeșakhețair atha sahitas tv avalokito 'vaśeșaih \|

1 atha] ca add. K T M || phalārtham eva] phalārthaiva M 3 atha] om. B N G 6 atrāntara] atrānta M 7 grahād] grahā B N G 8 saṃdhitah śodhyo] sandhimac chodhyo K M 10 -ānumānena] -ānumanina $\mathrm{K} \|$ gamana] gamanam $\mathrm{K} T \quad 11$ śubham aśubhaṃ] śubhāśubhaṃ K T M 13 vit] vā B N; jña G \| sahitaś ca] sahitatsa B G; sahita*sa N 14 'vaśeșaiḥ] 'vaśeșe B G

4-5 graha ... viśopakāḥ] TM $17 \quad$ 7-8 ādya ... tathādhike] PBh 16 $\quad$ 9-10 bhāvatas ... vāstuṣu] TM 19

87 The point being made here is that the fundamental Indian horoscopic figure or chart (more commonly called the rāśikuṇ̂lali or 'figure of signs'), although its precise design varies regionally, consists of twelve segments representing the zodiacal signs, and that most astrological factors, such as the zodiacal dignities or debilities of the planets, their mutual configurations or aspects, etc., are judged from this figure. However, when so-called quadrant houses - based on the horizon and meridian circles quadrisecting the ecliptic, and producing twelve divisions not typically coinciding with the zodiacal signs - are used, a separate figure of houses must be drawn up for that purpose, with the planets located in the correct divisions. 
[this] figure of houses is solely for the purpose of [ascertaining] the results of the houses. Every other judgement in the Tajika [science] is to be made from the figure of the planets [in the zodiacal signs]: so say the ancients. ${ }^{87}$

Next, the calculation of the twenty-point strength of a house is described in [Täjika]muktāvali [17]:

The distance between the planet and the [house] junction is divided by the distance between the house [cusp] and the junction. The result should be known as the house strength; one third of that is the twentypoint strength. ${ }^{88}$

Here, a special rule on measuring the difference is described in Paddhati[ bhüșaṇa 16]:

The former junction should be subtracted from the planet [and] from the house [cusp] when [the longitude of] the planet is less than [that of] the house [cusp]; likewise, the planet [and] the house [cusp] should be subtracted from the junction following the house [cusp] when [the longitude of the planet] is greater [than that of the house cusp].

[Continuing from Tājikamuktāvali 19]:

In nativities, annual [revolutions], [the taking of] vows and so forth, in journeys, questions and laying foundations, all results [are produced] by a house in proportion to the twenty-point strength.

Now, what sort of house will yield good or evil results by combining with [various] planets is described in the Täjikatilaka:

If joined to or aspected by its own ruler, Jupiter, Mercury and Venus, a house gives outstanding results, but not if joined to other planets or aspected by the others.

88 The house strength by this calculation will always be 1 or less. This value or rüpa is then converted to the next sexagesimal level (kalā or virüpa) through multiplication by 60 before being divided by 3 , thus yielding a maximum score of 20 as suggested by the name vimśopaka. 
atra vakșyamāṇabhāvabale sabalabhāvasya phaladātṛtvaṃ nirbalasya naiveti jñeyam | athāsmād grahād ayaṃ grahạ̣ kasmin sthāne 'stīti jñānārthaṃ yavanamatenetaretarasaṃkhyā uktā cintāmaṇau |

arkādibhyaś candrapūrvān salagnāms

tyaktvā śeșādholavāh pañcabhūmyah |

cen nyūnās tacchodhitāḥ śuddhimān syāt

tasmin rāśā vanyathā bhe parasmin || iti $\|$

iti daivajñavaryapaṇ̣itadāmodarātmajabalabhadraviracite hāyanaratne graharāśisvarūpavarṣapraveśādyānayanādhikāraḥ prathamaḥ ||1\|

1 bale] phale G p.c. 6 tacchodhitāh śuddhimān] tacchodhitāc chuddhimān B; tacchodhitāt chuddhimā N; tacchodhitāt chuddhimān G 
Here it should be understood that a house that is strong according to the [methods of calculating] house strength described below will [be able to] give results, [while] a house that is weak will not.

Next, for the sake of knowing in which place this planet is from that planet, the mutual reckoning according to the Yavana method is described in the Cintāmani:

Subtracting the moon and so forth, along with the ascendant, from the sun and so forth, the degrees remaining after [each] are fifteen: if [the degrees] subtracted are less, the subtracted [planet] will be [considered as located] in that [same] sign; otherwise, in the next sign. ${ }^{89}$

In the Hāyanaratna composed by Balabhadra, son of the learned Dāmodara, foremost of astrologers, this concludes the first topic: the natures of the planets and signs and the calculation of the revolution of the year and so forth.

89 A tentative translation, as the meaning is not quite clear. 